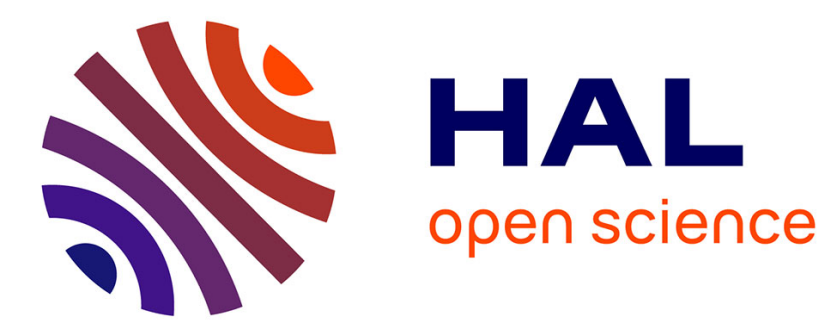

\title{
New chiral $\alpha$-aminophosphine oxides and sulfides: an unprecedented rhodium-catalyzed ligand epimerization
}

Jacques Andrieu, Jean-Michel Camus, Rinaldo Poli, Philippe Richard

\section{To cite this version:}

Jacques Andrieu, Jean-Michel Camus, Rinaldo Poli, Philippe Richard. New chiral $\alpha$-aminophosphine oxides and sulfides: an unprecedented rhodium-catalyzed ligand epimerization. New Journal of Chemistry, 2001, 25 (8), pp.1015-1023. 10.1039/B100217L . hal-03295881

\section{HAL Id: hal-03295881 \\ https://hal.science/hal-03295881}

Submitted on 28 Jul 2021

HAL is a multi-disciplinary open access archive for the deposit and dissemination of scientific research documents, whether they are published or not. The documents may come from teaching and research institutions in France or abroad, or from public or private research centers.
L'archive ouverte pluridisciplinaire HAL, est destinée au dépôt et à la diffusion de documents scientifiques de niveau recherche, publiés ou non, émanant des établissements d'enseignement et de recherche français ou étrangers, des laboratoires publics ou privés. 
New Chiral $\alpha$-Aminophosphine Oxides and Sulfides: an Unprecedented Rhodium-catalyzed Ligand Epimerization

Jacques Andrieu*, Jean Michel Camus, Rinaldo Poli and Philippe Richard

Laboratoire de Synthèse et d'Electrosynthèse Organométalliques, Université de Bourgogne, Faculté des Sciences "Gabriel", 6 Boulevard Gabriel, 21000 Dijon, France

Proofs to : Dr Jacques Andrieu

Laboratoire de Synthèse et d'Electrosynthèse Organométalliques

Université de Bourgogne, Faculté des Sciences "Gabriel"

6, Boulevard Gabriel, 21000 Dijon, France

e-mail : Jacques.Andrieu@u-bourgogne.fr 


\section{Illustrated Contents}

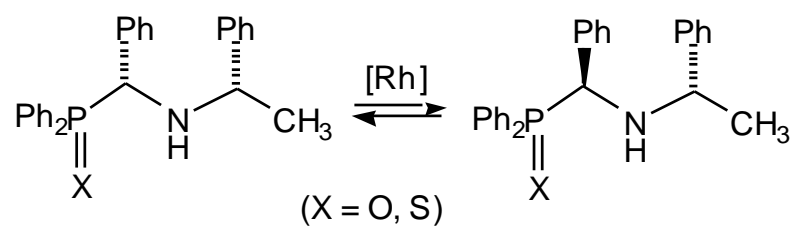




\begin{abstract}
New chiral $\alpha$-aminophosphine oxide $\mathrm{N}, \mathrm{P}(\mathrm{O})$ and sulfide $\mathrm{N}, \mathrm{P}(\mathrm{S})$ ligands have been prepared in one pot syntheses by addition of $\mathrm{Ph}_{2} \mathrm{PH}$ to $(S)-\mathrm{PhCH}=\mathrm{NCH}(\mathrm{Ph}) \mathrm{CH}_{3}$ followed by oxidation with $\mathrm{O}_{2}$ or $\mathrm{S}_{8}$. Crystallization from cold methanol leads to the isolation of an enantiomerically pure single N,P(O) diastereomer and to a 1:1 mixture of the two N,P(S) diastereomers. The coordination chemistry of these ligands with $[\mathrm{RhCl}(\mathrm{COD})]_{2}$ and $\left[\mathrm{RhCl}(\mathrm{CO})_{2}\right]_{2}$ has been investigated under either argon or syngas. At high temperatures, a P-C oxidative addition of the $\mathrm{N}, \mathrm{P}(\mathrm{O})$ ligand followed by imine elimination leads to several hydrido rhodium species. The complexes containing $\mathrm{N}, \mathrm{P}(\mathrm{S})$ ligand undergo the same process at room temperature. Catalytic amounts of the rhodium complexes catalyze the epimerization of the N,P(S) ligand under argon at room temperature, the dicarbonyl complex being 14 times more active than the COD complex. The same catalyzed epimerization takes place also for the $\mathrm{N}, \mathrm{P}(\mathrm{O})$ ligand, but only much more slowly at $35^{\circ} \mathrm{C}$ and under a syngas pressure. Possible mechanisms for this catalytic process are discussed. Catalytic tests in styrene hydroformylation have shown high activities and regioselectivities, but no enantioselectivities, for the $\mathrm{N}, \mathrm{P}(\mathrm{O})$-containing rhodium complexes.
\end{abstract}

Keywords: Hydroformylation, phosphine oxides and sulfides, aminophosphines, epimerization, rhodium 


\section{Introduction}

The challenge of asymmetric hydroformylation is not only related to chemoselectivity (hydroformylation vs. hydrogenation) and regioselectivity (branched $v s$. normal aldehyde), but also to enantioselectivity. ${ }^{1,2}$ The hydroformylation of vinyl aromatics leads mainly to branched aldehydes, which can be further oxidized to the corresponding acids. These compounds are effective nonsteroidal analgesics. ${ }^{3,4}$ Rhodium complexes containing chiral diphosphine ligands give higher activity and regioselectivity $v s$. platinum complexes, with moderate enantiomeric excesses (e.e.). However, by using diphosphite and phosphine-phosphite ligands, the enantioselectivity has been improved to 90 and more than $94 \%$, respectively. ${ }^{5,6}$ Three reviews on asymmetric hydroformylation have been published during the last five years. ${ }^{1,2,7}$ If chiral phosphorus ligands seem to be very attractive for this reaction, most of them are air-sensitive and their preparation is rather tedious. Recently described chiral thioureas are the first air stable ligands leading to a significant enantioselectivity ( $40 \%$ e.e.), albeit with a low conversion of 7 $\% .{ }^{8}$ Since there is a strong demand for air-stable and easily accessible chiral ligands, we decided to develop new air stable chiral aminophosphine oxide ligands (hereafter abbreviated as $\mathrm{N}, \mathrm{P}(\mathrm{O})$ ) and related sulfide ligand $(\mathrm{N}, \mathrm{P}(\mathrm{S}))$. In fact, ligands such as $\mathbf{A}$ or $\mathbf{B}$ in Chart 1 give not only greater catalytic activities in hydroformylation than their corresponding aminophosphines in combination with rhodium, but also higher branched/normal aldehyde ratios. ${ }^{9-11}$ It is notable that a set of optically pure $\alpha$-aminophosphine oxide ligands $\left(\mathrm{P}-\mathrm{C}^{*}-\mathrm{N}\right)$ of type $\mathbf{A}$ has recently been obtained by catalytic enantioselective addition of diphenylphosphine oxide to cyclic imines. ${ }^{12}$ To the best of our knowledge, the use of such chiral $\alpha$-aminophosphine oxides and sulfides (of type $\mathbf{A}$ ) has not so far been reported in asymmetric hydroformylation. We note, however, that a good conversion 
(85\%) with a high enantioselectivity ( $84 \%$ ) has recently been reported for the N,P(O) ligand $\mathbf{C}$ in the Ru-catalyzed transfer hydrogenation of phenylisopropyl ketone. ${ }^{13}$ In this paper, we present the synthesis of new chiral $\alpha$-aminophosphine oxides and sulfides with secondary amine function, and their use in asymmetric hydroformylation of olefins. Our results show that these ligands are not good chiral auxiliaries for the enantioselective branched hydroformylation and that they epimerize rapidly in the presence of rhodium.

$<$ Insert Chart 1>

\section{Results and Discussion}

\section{Synthesis of the aminophosphine oxide and sulfide ligands}

In order to obtain optically pure ligands, we based our synthetic approach on the two simple reactions in chart 2. The first step, namely the addition of $\mathrm{Ph}_{2} \mathrm{PH}$ to an imine, has already been studied and recently reported by us. The addition proceeds to an equilibrium position which was found to be strongly affected by the electron richness of the system. ${ }^{14,15}$ The second step consists of an oxidation reaction with either oxygen or sulfur. We used an optically active starting imine compound, namely $(S)-\mathrm{PhCH}=\mathrm{NCH}(\mathrm{Ph}) \mathrm{CH}_{3}$, in order to induce chirality at the central $\mathrm{C}$ atom and hopefully lead to a single diastereomer or to two diastereomers that could be easily separated by virtue of their different solubility properties. 
Before realizing the one-pot preparation of the N,P(O) and N,P(S) ligands, we wished to examine in more detail the previously communicated ${ }^{14}$ equilibrium between the starting imine and $\mathrm{Ph}_{2} \mathrm{PH}$ mixture and the two diastereomers of the intermediate aminophosphine $\mathbf{1}$ (equation 1). An NMR study in $\mathrm{CDCl}_{3}$ showed that an equilibrium was achieved after 5 hours at room temperature.

$<$ Insert Equation 1>

Figure 1 shows the time evolution of the diastereomers syn -1 $(R, S)$ and anti $\mathbf{- 1}(S, S)$ from a ${ }^{1} \mathrm{H}$ NMR monitoring in $\mathrm{CDCl}_{3}$. The absolute configurations were determined by analogy with both diastereomers of compound $\mathrm{CH}_{3} \mathrm{CH}(\mathrm{Ph}) \mathrm{NHCH}(\mathrm{Ph}) \mathrm{CH}_{3}$, which give signals for the benzylic and methine hydrogens at higher fields for the $(S, S)$ diastereomer than for the $(R, S)$ one. ${ }^{16}$ This was explained by assuming a zig-zag conformation together with anti and syn dispositions of the aryl groups in the $(S, S)$ and $(R, S)$ diastereomers, respectively. ${ }^{17}$ Hence, in the anti or $(S, S)$ isomer each benzylic hydrogen is subjected to the ring current effect of the non-adjacent aryl group. Then, the ${ }^{1} \mathrm{H}-\mathrm{NMR}$ spectra (see experimental section) differ significantly, especially for the benzyl and methine signals. ${ }^{16}$

\section{$<$ Insert Figure 1 $>$}

It is interesting to note from Figure 1 that both syn and anti stereoisomers form at approximately the same rate at the beginning of the reaction. However, the diastereomeric ratio 
changes remarkably after ca. 15 minutes. Indeed, the anti diastereomer continues to form whereas the amount of the syn one decreases until an equilibrium is reached, which corresponds to a diastereomeric excess (d.e.) of $62 \%$ in favor of the anti $\alpha-\mathrm{P}, \mathrm{N}$ ligand. This means that the two imine enantiofaces are equally accessible to the phosphine attack, but the reversible P-C bond formation equilibrium eventually puts the process under thermodynamic control, to yield and equilibrium constant of $\mathrm{K}_{\text {anti/syn }}=4.25$. Clearly, because of the above equilibrium, it is impossible to separate the two diastereomers of $\mathbf{1}$.

After achieving equilibrium, the reaction mixture was then slowly oxidized (by opening the NMR sample to air). The half time of this oxidation reaction is estimated to be ca. 4 hours and the oxidation process is irreversible. This irreversibility is demonstrated by the stability of the pure $(R, S)$ amino-phosphine oxide (obtained by crystallization, see below) toward epimerization in $\mathrm{CDCl}_{3}$ solution. In a preparative scale process carried out in $\mathrm{Et}_{2} \mathrm{O}$ as solvent, the air-stable aminophosphine oxide ligand $\mathrm{Ph}_{2} \mathrm{P}(\mathrm{O}) \mathrm{CH}(\mathrm{Ph}) \mathrm{NHCH}(\mathrm{Ph}) \mathrm{CH}_{3}$, 2, forms with a poor d.e. (syn) of $12 \%$ (Scheme 1). As diastereomers should exhibit different solubility properties, a separation by fractional crystallization was attempted. White needles of the pure syn-2 diastereomer were obtained quantitatively by a single crystallization from cold methanol. The ${ }^{1} \mathrm{H}$ and ${ }^{31} \mathrm{P}\left\{{ }^{1} \mathrm{H}\right\} \mathrm{NMR}$ analyses confirmed the presence of the single syn $\mathbf{- 2}$ diastereomer. The $(\mathrm{R}, \mathrm{S})$ configuration of the chiral carbon atoms is confirmed by the X-ray structural analysis (see below).

When the oxidation reaction was carried out in a $\mathrm{CH}_{2} \mathrm{Cl}_{2}$ solution with sulfur instead of oxygen, the ${ }^{1} \mathrm{H}$ and ${ }^{31} \mathrm{P}\left\{{ }^{1} \mathrm{H}\right\} \mathrm{NMR}$ analyses of the crude product showed complete conversion after one week. The irreversibility of this transformation is shown, like for the oxide derivative, by the stability of the crystallized sample toward epimerization (vide infra). The aminophosphine sulfide ligand $\mathrm{Ph}_{2} \mathrm{P}(\mathrm{S}) \mathrm{CH}(\mathrm{Ph}) \mathrm{NHCH}(\mathrm{Ph}) \mathrm{CH}_{3}, \mathbf{3}$, forms with a moderately high d.e. (anti) of 70 
$\%$ (Scheme 1). The different d.e.'s in the oxygen and sulfur oxidations must result from a kinetic control during the addition reaction of $\mathrm{Ph}_{2} \mathrm{P}(\mathrm{E}) \mathrm{H}(\mathrm{E}=\mathrm{O}$ or $\mathrm{S})$ to the imine. Indeed, the ${ }^{31} \mathrm{P}$ NMR spectra of aliquots withdrawn during both oxidation reactions never show the presence of free $\mathrm{Ph}_{2} \mathrm{PH}$. Rather, signals corresponding to $\mathrm{Ph}_{2} \mathrm{P}(\mathrm{E}) \mathrm{H}(\mathrm{E}=\mathrm{O}$ or $\mathrm{S})$ are observed.

$<$ Insert Scheme 1 $>$

Unfortunately, attempts to separate the two diastereomers of $\mathbf{3}$ by crystallization from cold methanol as described for the analogous oxide ligand led to a 1:1 diastereomeric mixture in $29 \%$ isolated yields. Thus, the solution is completely depleted from isomer syn-3 and pure anti-3 should remain in solution. Isolation of the pure anti-3 ligand from the residual filtrate, however, was prevented by the traces of unreacted $\mathrm{Ph}_{2} \mathrm{P}(\mathrm{S}) \mathrm{H}$.

\section{X-ray structural analyses of ligands 2 and 3}

Suitable crystals of syn -2 and syn/anti-3 (1:1) for the X-ray diffraction analyses were obtained under identical conditions (see Experimental section). Nevertheless, quite surprisingly, the unit cell of the $\mathrm{N}, \mathrm{P}(\mathrm{O})$ ligand contains only the $(R, S)$ diastereomer, whereas the $\mathrm{N}, \mathrm{P}(\mathrm{S})$ ligand leads instead to the co-crystallization of the $(R, S)$ and $(S, S)$ isomers. The absolute configuration observed for the aminophosphine oxide confirms the assignment made earlier on the basis of NMR. Neither compound shows any inter- or intramolecular $\mathrm{NH}^{\cdots} \mathrm{E}$ bonding interaction. Consequently, both are present as monomers in the solid state (see Figures $2 \mathrm{a}$ and $2 \mathrm{~b}$ ). 
$<$ Insert Figure 2 $>$

Selected bond lenghts and angles are reported in Table 1. The P-C(1) bond lenghts in the N,P(S) ligand (1.893(2) and 1.856(2) $\AA$ for the syn and anti diastereomers, respectively) are longer than those found in its oxide counterpart (1.832(2) §̊). This can directly be correlated with the weaker electron withdrawing effect of the sulfur atom relative the oxygen atom. This difference indicates that it should be easier to cleave the P-C(1) bond for the N,P(S) ligand than for the

aminophosphine oxide. Moreover, in contrast to the average P-C bond lenght found from 19 other structures containing the $\mathrm{Ph}_{2} \mathrm{P}(\mathrm{S})-\mathrm{C}\left(s p^{3}\right) \mathrm{H}$ moiety in the Cambridge Crystallographic Database, which is $1.83(1) \AA$, the $\mathrm{P}-\mathrm{C}(1)$ bond lenght in the syn- $\mathbf{3}$ diastereomer is abnormally longer. This further indicates that this latter P-C bond could be easier to cleave. These assumption will be confirmed in a later section concerning the rhodium catalyzed epimerization. It is also notable that this isomer with the unusually long P-C bond, therefore presumably having a higher relative energy, corresponds indeed to the minor diastereomer at equilibrium according to the NMR analysis. It can be noted that the $\mathrm{P}-\mathrm{C}(1)-\mathrm{N}$ angle is significantly different in the two diastereomers of $\mathbf{3}$ and that no clear correlation exists between syn-2 and syn-3 for this parameter.

$<$ Insert Table 1 $>$

\section{Interaction of ligands 2 and 3 with rhodium complexes}

Before carrying out catalytic tests, the stoichiometric interactions between the $\mathrm{N}, \mathrm{P}(\mathrm{O})$ and $\mathrm{N}, \mathrm{P}(\mathrm{S})$ ligands and the rhodium precatalysts $[\mathrm{RhCl}(\mathrm{COD})]_{2}$ and $\left[\mathrm{RhCl}(\mathrm{CO})_{2}\right]_{2}$ were investigated. 
Stirring a $2: 1$ mixture of syn $\mathbf{- 2}$ and $[\mathrm{RhCl}(\mathrm{COD})]_{2}$ in $\mathrm{CDCl}_{3}$ solution for 15 minutes at room temperature leads to a single product which, according to the NMR analyses, has an uncoordinated $\mathrm{P}=\mathrm{O}$ moiety $\left({ }^{31} \mathrm{P}\right.$ NMR chemical shift identical to the free ligand), see Scheme 2. The N-coordination is not clearly shown by the ${ }^{1} \mathrm{H}$ NMR because of overlap of the NH resonance with those of the coordinated cyclooctadiene protons. However, this coordination can reasonably be expected considering the ability of secondary amines to split the chloride bridges in $[\mathrm{RhCl}(\mathrm{COD})]_{2}$, as previously proposed (although without spectroscopic evidence) for analogous $\alpha$-aminophosphonate ligands. ${ }^{18}$ The above solution was then heated to $80^{\circ} \mathrm{C}$ for 15 minutes. After evaporation of the solvent, the ${ }^{1} \mathrm{H}$ and ${ }^{31} \mathrm{P}$ NMR spectra in $\mathrm{C}_{6} \mathrm{D}_{6}$ show at least four different hydrido rhodium complexes (D) and the presence of free imine. These products presumably result from a P-C oxidative addition followed by imine elimination (Scheme 2). Note that the $\mathrm{Rh}(\mathrm{III})$ $\mathrm{PPh}_{2}(\mathrm{O})$ moiety has recently been identified by X-ray diffraction analysis in dirhodium chloride complexes. ${ }^{19}$ At a temperature as low as $55^{\circ} \mathrm{C}$, similar hydrido rhodium species begin to appear after 4 hours in very minor quantities. The same NMR resonances are generated in a control experiment involving the addition of $\mathrm{Ph}_{2} \mathrm{P}(\mathrm{O}) \mathrm{H}$ to the same rhodium substrate at $80^{\circ} \mathrm{C}$ in $\mathrm{C}_{6} \mathrm{D}_{6}$.

\section{$<$ Insert Scheme 2>}

The addition of compound syn-2 to $\left[\mathrm{RhCl}(\mathrm{CO})_{2}\right]_{2}$ at room temperature, on the other hand, leads to a rhodium complex containing a bidentate N,P(O) ligand, which is stable in solution for several hours. The bidentate coordination mode is confirmed by a new broad peak of the phosphine oxide moiety at 40.7 vs. 31.5 ppm for the free ligand and by the $v_{\mathrm{P}=\mathrm{O}}$ absorption band at 1184 vs. $1265 \mathrm{~cm}^{-1}$ for the free ligand. In addition, the $\mathrm{NH}$ resonance in the ${ }^{1} \mathrm{H}$ NMR spectrum 
is also shifted to lower field by coordination. However, two IR absorption bands in $\mathrm{CDCl}_{3}$ at 2086 and $2015 \mathrm{~cm}^{-1}$ indicate the presence of two types of terminal carbonyl ligands. This observation, combined with the broad signals in the ${ }^{1} \mathrm{H}$ and ${ }^{31} \mathrm{P}$ NMR spectra, suggest a dynamic isomerization exchange, i.e. $(\mathbf{E})$ in Scheme 2, similar to that reported for complex $\mathrm{RhCl}(\mathrm{CO})\left(\kappa^{2}-\right.$ $\mathrm{N}, \mathrm{P}(\mathrm{O})$ ) with $\mathrm{N}, \mathrm{P}(\mathrm{O})=\mathrm{Ph}_{2} \mathrm{P}(\mathrm{O}) \mathrm{CH}_{2} \mathrm{NMe}_{2} .{ }^{9}$ When this reaction was carried out under a $\mathrm{CO}$ atmosphere (by preparing $\left[\mathrm{RhCl}(\mathrm{CO})_{2}\right]_{2}$ in situ from $[\mathrm{RhCl}(\mathrm{COD})]_{2}$ under $\mathrm{CO}$ ), the same complexes $(\mathbf{E})$ are obtained. However, a new square planar compound also forms, in which the $\mathrm{P}=\mathrm{O}$ moiety is uncoordinated due to the hemilabile character of the ligand under $\mathrm{CO}$.

The stoichiometric reaction between the N,P(S) ligand (1:1 mixture of syn and anti diastereomers of 3) with $\left[\mathrm{RhCl}(\mathrm{CO})_{2}\right]_{2}$ (or with $[\mathrm{RhCl}(\mathrm{COD})]_{2}$ under $\mathrm{CO}$ ) at room temperature either in $\mathrm{CDCl}_{3}$ or $\mathrm{C}_{6} \mathrm{D}_{6}$ led, after 30 minutes, to a mixture of four rhodium complexes according to the ${ }^{31} \mathrm{P}$ NMR spectrum. The two major products are characterized by ${ }^{31} \mathrm{P}$ singlets at 50.42 and $50.25 \mathrm{ppm}$ in $\mathrm{CDCl}_{3}$, i.e. close to the chemical shifts of the two diastereomers of the free ligand. Integration shows that the d.e. has surprisingly changed from $0 \%$ in the free ligand to $70 \%$ in the $\mathrm{Rh}$ products. The N-coordination mode is confirmed by the ${ }^{1} \mathrm{H}$ NMR chemical shift of the $\mathrm{NH}$ proton from 3.55 for the free amine to $3.80 \mathrm{ppm}$ in $\mathrm{C}_{6} \mathrm{D}_{6}$ solution. Therefore, in contrast to the same reaction of the $\mathrm{N}, \mathrm{P}(\mathrm{O})$ ligand described above, ligand 3 binds rhodium in the $\kappa^{1}-N$ fashion. This is surprising because the reaction of the very similar ligand $\mathrm{Ph}_{2} \mathrm{PCH}_{2} \mathrm{P}(\mathrm{S}) \mathrm{Ph}_{2}$ with $\left[\mathrm{RhCl}(\mathrm{CO})_{2}\right]_{2}$ was reported to lead to $\mathrm{RhCl}(\mathrm{CO})\left(\kappa^{2}-\mathrm{Ph}_{2} \mathrm{PCH}_{2} \mathrm{P}(\mathrm{S}) \mathrm{Ph}_{2}\right)$ in which the ${ }^{31} \mathrm{P}$ NMR resonance for the $\mathrm{P}(\mathrm{S}) \mathrm{Ph}_{2}$ moiety shifts to $52 \mathrm{ppm}$ from the free ligand value of 40 ppm. ${ }^{20,21}$

The other two reaction products exhibit ${ }^{31} \mathrm{P}$ NMR doublets at 114 (with $\mathrm{J}_{\mathrm{PRh}}=179 \mathrm{~Hz}$ ) and at $71 \mathrm{ppm}$ (with $\mathrm{J}_{\mathrm{PRh}}=147 \mathrm{~Hz}$ ), showing the direct interaction of the rhodium center with phosphorus rather than with sulfur. These signals can likely be assigned to two types of Rh-P species that we have not been able to fully characterize, likely formed by a P-C oxidative addition process. These chemical shifts and the high $\mathrm{Rh}-\mathrm{P}$ coupling constants may be consistent with terminal or bridging $(\mu: P, S)$ modes for the $\mathrm{P}(\mathrm{S}) \mathrm{Ph}_{2}$ ligand, both of which have previously been established. ${ }^{22,23}$ At this point, we conclude that rhodium complexes containing the N,P(S) ligand 
3 are unstable in solution even at room temperature. Finally, since the complexes containing the $\mathrm{N}, \mathrm{P}(\mathrm{O})$ ligand syn -2 are unstable only at high temperatures and since low temperatures are known to decrease the conversion rate but at the same time favor higher enantioselectivities in hydroformylation reactions, $2,6,24$ we decided to examine the catalytic activity of Rh complexes containing the ligand syn $-\mathbf{2}$ at relatively low temperatures $\left(\leq 55^{\circ} \mathrm{C}\right)$.

\section{Rhodium-catalyzed hydroformylation of styrene with ligands syn-2 and 3}

The results of all catalytic studies are assembled in Table 2. All runs were carried out at a temperature of 55 or $35^{\circ} \mathrm{C}$, and at a total pressure of 400 or 500 psi for the $1: 1 \mathrm{CO} / \mathrm{H}_{2}$ mixture, in chloroform or in benzene as solvent. A control catalytic run without ligand (entry 1) shows complete conversion after $20 \mathrm{~h}$ with a b/1 regioselectivity of $89 / 11$. By using $\mathrm{Eu}(\mathrm{hfc})_{3}$ as a chemical shift reagent, no e.e. was observed, as expected. In the presence of ligand syn-2 (run 2) the conversion rate is five times higher with the same regioselectivity, but with zero enantioselectivity. The use of the less polar solvent $\mathrm{C}_{6} \mathrm{H}_{6}$ (run 3) decreases the activity. Unfortunately, the regioselectivity is moderate and the catalyst is still non-enantioselective even though benzene is known to be the best solvent to favor high regioselectivities and to prevent the aldehyde epimerization. ${ }^{5,6}$ Slightly lower activities and zero enantioselectivity are also observed by working at a lower temperature in chloroform (run 4), however the b/l ratio is greatly increased under these conditions.

$<$ Insert Table 2> 
The promoter effect of ligand syn-2 is further demonstrated by the following additional experiments. The conversion was found to be linear with time (zero order dependence on substrate) and dependent of the ligand/metal ratio as illustrated in Figure 3 for experiments carried out in chloroform at $35^{\circ} \mathrm{C}$. In all cases, the regioselectivity is greater than $95 / 5$ and the enantioselectivity is zero. The highest activity corresponds to a ligand/metal ratio of $1: 1$, while it is much lower for a ratio of $0.5: 1$, slighly lower for $2: 1$, and then it decreases dramatically when a ratio of $10: 1$ is used. The TOF for the experiment with 0.5 equivalents of ligand (10.2 mol $\left.\operatorname{mol}(\mathrm{Rh})^{-1} \mathrm{~h}^{-1}\right)$ is approximately one half the TOF found with 1 equivalent of ligand (21.6 mol $\left.\operatorname{mol}(\mathrm{Rh})^{-1} \mathrm{~h}^{-1}\right)$. A possible interpretation of these results is that only one half the amount of rhodium forms the complex containing the aminophosphine oxide ligand and subsequently the activity is decreased by a factor of two, while higher ratios likely force the coordination of two or more ligands to the rhodium center via equilibrium processes, consequently decreasing the number of coordination sites and leading to less active species.

$<$ Insert Figure 3 $>$

Since ligand syn -2 promotes the activity of the rhodium catalyst for the hydroformylation of styrene, other olefins have also been tested under the same conditions. Methylmethacrylate did not yield aldehydes after one day, and a conversion of only $7 \%$ was achieved with $\alpha$-methylstyrene after $70 \mathrm{~h}$. This catalytic system seems to be best suited for the hydroformylation of electron-deficient vinyl aromatics. Since, in some cases, better e.e.'s have been obtained with vinyl naphthalene instead of styrene, ${ }^{24,25}$ this olefin was also tested, yielding 
results comparable to styrene. The activity is slightly lower, the regioselectivity is about the same (entry 5), and the e.e. is quite small (3\%).

Use of the N,P(S) ligand 3 with neutral or cationic rhodium precursors gave dramatically lower activities (see entries 6 and 7 in Table 2), albeit with surprisingly high regioselectivities, by analogy with the previous studies with the $\mathrm{Ph}_{2} \mathrm{P}(\mathrm{E}) \mathrm{CH}_{2} \mathrm{NMe}_{2}\left(\mathrm{E}=\mathrm{S} v\right.$ s. O) ligands. ${ }^{9,}{ }^{10}$ The rapid decomposition of the $\mathrm{Rh}$ complexes with ligand $\mathbf{3}$ mentioned in the previous section may rationalize these results. In other cases, on the other hand, cationic precursors displayed increased activities. $^{8,26}$

The last experiment in Table 2 (run 8) shows that the use of the phosphine oxide $\mathrm{Ph}_{2} \mathrm{P}(\mathrm{O}) \mathrm{H}$ leads to a poorer catalytic performance relative to ligand syn-2 (entry 4). The reaction of this phosphine oxide with the rhodium precursor, as shown in the previous section, leads to the same products originating from the thermal decomposition of the rhodium complex with ligand syn -2 (form $\mathbf{D}$ in Scheme 2). This result further demonstrates that the coordinated aminophosphine oxide is an efficient ligand for styrene hydroformylation catalysis under conditions where this decomposition do not occur.

The observed racemic mixture of the branched aldehyde product could well result from an aldehyde racemization reaction ${ }^{8}$ but, considering the relatively short reaction time, we concluded that this can not be the only reason to rationalize the absence of enantioselectivity. Thus, we wished to investigate the interaction between the rhodium center and ligands $\mathbf{2}$ and $\mathbf{3}$ in more detail.

\section{Rhodium-catalyzed epimerization of aminophosphine oxide and sulfide ligands}


We have mentioned above that the aminophosphine sulfide is not efficient in hydroformylation. However, an NMR investigation of the interaction between $\mathbf{3}$ and $\left[\mathrm{RhCl}(\mathrm{CO})_{2}\right]_{2}$ surprisingly showed that rhodium induces ligand epimerization. Upon $\mathrm{Rh}$ coordination, the anti/syn ratio (as determined by ${ }^{31} \mathrm{P}$ NMR integration) changes from 50:50 to 85:15 after ca. 30 minutes. The final ratio of the two coordinated ligand diastereomers corresponds to the ratio of the two free diastereomers before crystallization (see Scheme 2). Since all signal intensities do not further change after several hours (including those of the other by-products, see section 3 ), all compounds are considered to be in a thermodynamic equilibrium situation. We were then stimulated to interact the ligand $\mathbf{3}$ with a catalytic amount of $[\mathrm{RhCl}(\mathrm{COD})]_{2}$. The complete equilibration was achieved after 8 hours instead of 30 minutes (see Figure 4), to yield again the same anti/syn ratio of 85:15. As mentioned earlier (see X-ray structure analysis discussion in section 2), the smaller stability of the syn diastereomer may be the consequence of its longer P-C(1) bond length.

\section{$<$ Insert Figure 4>}

Under the same conditions, the chlorodicarbonylrhodium(I) dimer exhibits a higher activity leading to a complete equilibration after less than one hour (see Figure 4). To the best of our knowledge, there is only one example of ligand epimerization (for the bifunctional S,O ligand (R)-2-[(R)-phenylsulfinyl]propionic acid) upon stereoselective and stoichiometric coordination to hemimetallocenic $\mathrm{Rh}^{\mathrm{III}}$, $\mathrm{Ir}^{\mathrm{III}}, \mathrm{Ru}^{\mathrm{II}}$ or $\mathrm{Os}{ }^{\mathrm{II}}$ complexes. ${ }^{27}$ Here, we report the first case where such a process is Rh-catalyzed. By applying the kinetic analysis of reversible first order reactions to our experimental measurements (eq. 2), a satisfactory fitting is obtained (see Figure 5), giving rate 
constants $\mathrm{k}_{\text {obs }}$ of $8.6(2) \cdot 10^{-3}\left(\mathrm{t}_{1 / 2}=80 \mathrm{~min}, \mathrm{R}^{2}=0.996\right)$ and of $0.117(4) \min ^{-1}\left(\mathrm{t}_{1 / 2}=5.9 \mathrm{~min}, \mathrm{R}^{2}=\right.$ $0.994)$ for systems using $[\mathrm{RhCl}(\mathrm{COD})]_{2}$ and $\left[\mathrm{RhCl}(\mathrm{CO})_{2}\right]_{2}$, respectively. This means that the conversion rate with the latter catalyst is ca. 14 times faster, which may be related to the higher electrophilic character of the rhodium center in this catalytic system.

$\mathrm{k}_{\mathrm{obs}} \mathrm{t}=\ln \left[\% \operatorname{syn}_{\mathrm{eq}} /\left(\% \operatorname{syn}_{\mathrm{t}} \mathrm{-} \% \operatorname{syn}_{\mathrm{eq}}\right)\right]$

$\left(\mathrm{k}_{\mathrm{obs}}=\mathrm{k}_{\mathrm{obs}}+\mathrm{k}_{\mathrm{obs}-}\right.$ and $\left.\% \mathrm{syn}_{\mathrm{eq}}=15 \%\right)$

$<$ Insert Figure 5>

From the values of the equilibration rate constants ( $\left.\mathrm{k}_{\mathrm{obs}}+\mathrm{k}_{\mathrm{obs}}\right)$ and the equilibrium constant $\left(\mathrm{k}_{\mathrm{obs}}+\mathrm{k}_{\mathrm{obs}-}\right)$, the individual values of $\mathrm{k}_{\mathrm{obs}}$ and $\mathrm{k}_{\mathrm{obs}-}$ may be derived. Experiments with different catalyst concentrations have not been carried out. However, under the reasonable assumption that both direct and reverse reactions are first order in the catalyst (a catalyst influence on the rate is shown by the shorter equilibration time when the rhodium complex was used stoichiometrically), namely $\mathrm{k}_{\mathrm{obs}+/}=\mathrm{k}_{+/[}[\mathrm{Rh}]$, the second order rate constants $\mathrm{k}_{+}$and $\mathrm{k}$ - for the $[\mathrm{RhCl}(\mathrm{COD})]_{2}$ catalyzed process are 7.31(3) $\times 10^{-2}$ and $1.29(3) \times 10^{-2} \mathrm{~mol}^{-1} 1 \mathrm{~min}^{-1}$, while those for the $\left[\mathrm{RhCl}(\mathrm{CO})_{2}\right]_{2}$ catalyzed process are $0.995(6)$ and $0.175(6) \mathrm{mol}^{-1} 1 \mathrm{~min}^{-1}$, respectively (see Scheme $3)$.

$<$ Insert Scheme 3> 
In the case of the $\mathrm{N}, \mathrm{P}(\mathrm{O})$ ligand, no epimerization could be detected by using $[\mathrm{RhCl}(\mathrm{COD})]_{2}$ even after 24 hours. However, a slow epimerization was observed when the same experiment was conducted under a monoxide pressure and even faster under a syngas pressure (see Figure 6).

$<$ Insert Figure 6>

The increased rate in the presence of hydrogen suggests that a hydride species formed in situ catalyzes more efficiently this epimerization process. This state of affairs is analogous to that described for a rhodium-catalyzed reversible $\mathrm{P}-\mathrm{C}$ bond cleavage of $\mathrm{PPh}_{3}{ }^{28,}{ }^{29}$ The more difficult epimerization for the $\mathrm{N}, \mathrm{P}(\mathrm{O})$ ligand is probably the consequence of the stronger $\mathrm{P}-\mathrm{C}$ bond (see $\mathrm{X}$ ray structure analysis discussion), resulting from the stronger electron withdrawing effect of the oxygen atom $v s$. the sulfur atom.

Furthermore, Figure 6 shows a faster epimerization of the oxide ligand $\mathbf{2}$ when using a greater metal/ligand ratio, as also observed for the analogous sulfide ligand $\mathbf{3}$. Because of the more stringent epimerization conditions, further studies to establish the equilibrium position were not carried out. The d.e. obtained (12\%) after $24 \mathrm{~h}$ with a 5:1 ligand/metal ratio and under a syngas pressure is identical to the d.e. of the free ligand before crystallization (see Section 1). By comparison with the results of the sulfide ligand epimerization, this may well correspond to a thermodynamic equilibrium.

We now remark that the conditions leading to the extensive epimerization of ligand syn-2 (r.t., $24 \mathrm{~h}$ ) are comparable to the conditions used for the hydroformylation catalysis $\left(35^{\circ} \mathrm{C}, 3 \mathrm{~h}\right)$. In addition, an equimolar amount of $\mathrm{Rh}$ and ligand are used under the hydroformylation 
conditions, leading to an expected much faster epimerization. Indeed, a run of $s y n-\mathbf{2}: \mathrm{Rh}=1: 1$ under catalytic conditions (Table 2, entry 4 ) in the absence of styrene was stopped after $3 \mathrm{~h}$ and the recovered catalyst, upon treatment with tmeda, gave free 2 with a syn/anti ratio of 59:41 (18\% d.e.). It is then reasonable to propose that the failure to observe any e.e. for this catalytic hydroformylation may be related to the ligand epimerization under syngas conditions.

\section{Mechanistic considerations of the rhodium-catalyzed epimerization}

As the observed rhodium-catalyzed ligand epimerization appears to be an unprecedented phenomenon, we have considered its possible mechanism. Some suggestions may be formulated on the basis of previously established reactivity. Under appropriate conditions $\mathrm{C}_{\mathrm{ar}}-\mathrm{H}, \mathrm{C}_{\mathrm{sp} 3}-\mathrm{H}$ or $\mathrm{P}-$ $\mathrm{C}$ oxidative additions involving $\mathrm{PPh}_{3}$ or other functionalized phosphines take place with i.e. $\operatorname{Co}(\mathrm{I}), \operatorname{Rh}(\mathrm{I})$ or $\operatorname{Ir}(\mathrm{I})^{28-30}$. Two possible catalytic pathways have therefore been considered, involving reversible $\mathrm{C}-\mathrm{H}$ or $\mathrm{P}-\mathrm{C}$ bond cleavages as shown in Schemes 4 and 5, respectively.

$<$ Insert Schemes 4 and 5>

For the $\mathrm{N}, \mathrm{P}(\mathrm{O})$ epimerization, the best activities were observed under $\mathrm{CO}$ at high pressures, where the complex probably exists under the monodentate form $\operatorname{RhCl}(\mathrm{CO})_{2}\left(\kappa^{1}-\mathrm{N}, \mathrm{P}(\mathrm{O})\right)$ according to the stoichiometric studies (see Section 3). An equilibrium with the bidentate form, $\mathrm{RhCl}(\mathrm{CO})\left(\kappa^{2}-\mathrm{N}, \mathrm{P}(\mathrm{O})\right)$, however, is established at low $\mathrm{CO}$ pressures. For the $\mathrm{N}, \mathrm{P}(\mathrm{S})$ epimerization, on the other hand, the monodentate form $\mathrm{RhClL}_{2}\left(\kappa^{1}-\mathrm{N}, \mathrm{P}(\mathrm{S})\right)\left[\mathrm{L}_{2}=\mathrm{COD}\right.$ or $\left.(\mathrm{CO})_{2}\right]$ seems present for both catalysts. It seems likely that the bidentate coordination is not necessary for this catalytic transformation. 
For the $\mathrm{C}-\mathrm{H}$ pathway (Scheme 4), a reversible $\mathrm{C}_{\mathrm{sp} 3}-\mathrm{H}$ oxidative addition on the starting complex $(R)-\mathbf{F}$ would lead to the formation of intermediate $(R)-\mathbf{G}$, stabilized by coordination of the $\mathrm{P}=\mathrm{E}$ function in a pseudo-allylic moiety. Since the stereogenic carbon atom is blocked during this process, its reversal could only lead back to the starting absolute configuration. However, epimerization could occur via an $\eta^{3} / \eta^{1}$ equilibration of the pseudo allyl ligand to give intermediate $\mathbf{H}$, for which free rotation around the P-E single bond is possible. An alternative possibility is a reversible E-H reductive elimination to generate intermediate $\mathbf{I}$, for which an alternative N-bonded isomeric form is also possible. Reversal of all steps leads to $(S)$-F. It is interesting to remark that the $\mathrm{N}$-bonded isomer of $\mathbf{I}$ is a tautomeric form of the starting compound $(R)$-F. Therefore, transformation of $(R)$-F to $(S)$-F could also be achieved via this intermediate $\mathbf{I}$ without the need for the hydrogen atom to transit via the Rh center.

For the P-C pathway (Scheme 5), a reversible P-C oxidative addition from $(R)$-F leads to the 16-electron intermediate $(R)-\mathbf{J}$ which may be capable of deinserting the imine to lead to $(R)$ -

K. Inversion of configuration may be achieved at this point by $\eta^{2} / \eta^{1}$ imine rearrangement through $\mathbf{L}$, without a need to decoordinate the imine. On the other hand, we have shown that the imine is expelled from the $\mathrm{N}, \mathrm{P}(\mathrm{O})$ complex at high temperatures, with formation of a mixture of hydride products (see Section 3). As already stated above, a $\mathrm{Rh}(\mathrm{III})-\mathrm{PPh}_{2}(\mathrm{O})$ fragment in dirhodium chloride complexes have recently been proved by X-ray diffraction analysis. ${ }^{19}$ This experimental observation is the only tenuous criterion that currently makes us favour the P-C pathway.

\section{Conclusions and perspectives}

We have described what appears to be the first example of an interesting rhodium catalyzed epimerization process. The aminophosphine oxide ligand $\mathbf{2}$ is efficient and regioselective in the rhodium-catalyzed hydroformylation of styrene, but is not an asymmetric inducer ligand. The 
epimerization of the chiral center between the nitrogen and phosphorus atoms under the catalytic hydroformylation conditions may be related to this lack of enantioselective induction. The epimerization occurs by a mechanism that appears to involve a reversible P-C bond cleavage. This observation shows that this type of $\mathrm{N}, \mathrm{P}(\mathrm{O})$ ligand, albeit sufficiently active and regioselective, can not be used in asymmetric hydroformylation with rhodium catalysts. Furthermore, the corresponding N,P(S) ligand $\mathbf{3}$ generates a less efficient catalyst, because of an easier P-C oxidative addition and catalyst deactivation.

The development of enantioselective branched hydroformylation catalysts with this class of ligands requires structural modifications that block or strongly disfavour these epimerization and deactivation pathways. Efforts in this direction are currently being pursued in our laboratory. We also note that all epimerization mechanisms (except via direct tautomerization to intermediate $\mathbf{I}$ in Scheme 4) require an oxidative addition process. In the absence of rhodium, both ligands $\mathbf{2}$ and $\mathbf{3}$ are configurationally stable. Therefore, we are also interested in applying these ligands to enantioselective catalytic reactions with metals that cannot undergo oxidative addition processes.

\section{Experimental Section}

All reactions were carried out in Schlenk-type flasks under argon atmosphere. Solvents were purified and dried under dinitrogen by conventional methods. The ${ }^{1} \mathrm{H},{ }^{31} \mathrm{P}\left\{{ }^{1} \mathrm{H}\right\}$ and ${ }^{13} \mathrm{C}\left\{{ }^{1} \mathrm{H}\right\}$ NMR spectra were recorded at 200.13, 81.03 and $51.32 \mathrm{MHz}$, respectively, on a Bruker AC 200 instrument in $\mathrm{CDCl}_{3}$ solution. All chemical shifts are given in ppm. The infrared spectra were recorded in $\mathrm{CH}_{2} \mathrm{Cl}_{2}$ or in $\mathrm{CHCl}_{3}$ solution with an IFS 66 Perkin-Elmer instrument. The $\alpha$ rotation polarization angle was measured on the Perkin-Elmer 141 Polarimeter. The elemental analyses 
were carried out on a Fisons EA 1108 apparatus. The imine compound was prepared by a slow addition of stoechiometric amount of distilled benzaldehyde to a dichloromethane solution of $(S)$ methylbenzylamine at $0^{\circ} \mathrm{C}$, according to literature. ${ }^{31}$ The water formed was removed under vacuum at $120^{\circ} \mathrm{C}$ for $3 \mathrm{hrs}$. Compounds (S)-methylbenzylamine, sulfur, $[\mathrm{RhCl}(\mathrm{COD})]_{2}(\mathrm{COD}$ : 1,5-cyclooctadiene) and $\left[\mathrm{RhCl}(\mathrm{CO})_{2}\right]_{2}$ were obtained from commercial sources and used as received, while $\mathrm{Ph}_{2} \mathrm{PH}$ was prepared by the conventional method. ${ }^{32}$.

\section{Formation of $(R, S)$ - and $(S, S)-\mathrm{Ph}_{2} \mathrm{PCH}(\mathrm{Ph}) \mathrm{NHCH}(\mathrm{Ph}) \mathrm{CH}_{3}, 1$.}

To a solution of $(S)-\mathrm{PhCH}=\mathrm{NCH}(\mathrm{Ph}) \mathrm{CH}_{3}(0.060 \mathrm{~g}, 0.287 \mathrm{mmol})$ in $\mathrm{CDCl}_{3}(1 \mathrm{ml})$ was added $\mathrm{Ph}_{2} \mathrm{PH}(50 \mu \mathrm{l}, 0.287 \mathrm{mmol})$. The mixture was stirred for $12 \mathrm{hrs}$, yielding an equilibrium of 1 with the starting materials. NMR properties of compound 1: ${ }^{1} \mathrm{H}$ NMR $\left(\mathrm{CDCl}_{3}\right): \delta=7.85-6.87$ (m, aromatics) and $2.00(\mathrm{~s}, \mathrm{br}, \mathrm{NH})$, for $(R, S)-\mathbf{1}: 4.70\left(\mathrm{~d}, \mathrm{PCH},{ }^{2} J(\mathrm{PH})=4.9 \mathrm{~Hz}\right), 3.74(\mathrm{q}, \mathrm{NCH}$, $\left.{ }^{2} J(\mathrm{HH})=6.4 \mathrm{~Hz}\right), 1.36\left(\mathrm{~d}, \mathrm{CH}_{3},{ }^{2} J(\mathrm{HH})=6.4 \mathrm{~Hz}\right)$, for $(S, S)-1: 4.16\left(\mathrm{~d}, \mathrm{PCH},{ }^{2} J(\mathrm{PH})=5.4 \mathrm{~Hz}\right)$, $3.61\left(\mathrm{q}, \mathrm{NCH},{ }^{2} J(\mathrm{HH})=6.4 \mathrm{~Hz}\right), 1.28\left(\mathrm{~d}, \mathrm{CH}_{3},{ }^{2} J(\mathrm{HH})=6.4 \mathrm{~Hz}\right)$. d.e. $($ anti/syn $)=62 \% .{ }^{31} \mathrm{P}\left\{{ }^{1} \mathrm{H}\right\}$ $\operatorname{NMR}\left(\mathrm{CDCl}_{3}\right): 1.49(\mathrm{~s})$ for $(R, S)-\mathbf{1}$ and $0.89(\mathrm{~s})$ for $(S, S)-\mathbf{1}$.

\section{Air Oxidation of $(R, S)$ - and $(S, S)-1$. NMR monitoring}

To a solution of $(S)-\mathrm{PhCH}=\mathrm{NCH}(\mathrm{Ph}) \mathrm{CH}_{3}(0.060 \mathrm{~g}, 0.287 \mathrm{mmol})$ in $\mathrm{CDCl}_{3}(1 \mathrm{ml})$ was added $\mathrm{Ph}_{2} \mathrm{PH}(50 \mu \mathrm{l}, 0.287 \mathrm{mmol})$. After the equilibrium of 1 with the starting materials was attained $(3 \mathrm{~h})$, an air stream was directly introduced into the $\mathrm{CDCl}_{3}$ solution which was then stirred for 20 hrs. The ${ }^{31} \mathrm{P}\left\{{ }^{1} \mathrm{H}\right\}$ NMR spectrum showed that the oxidation reaction was nearly complete yielding both diastereomers of $\mathbf{2}$ with a d.e. (syn/anti) of $12 \%$. The NMR data of syn-2 are given in the next section. NMR data of anti-2: ${ }^{1} \mathrm{H}$ NMR $\left(\mathrm{CDCl}_{3}\right): \delta=7.45-6.88(\mathrm{~m}$, 
aromatics), $4.10\left(\mathrm{~d}, \mathrm{PCH},{ }^{2} J(\mathrm{PH})=9.9 \mathrm{~Hz}\right), 3.61\left(\mathrm{q}, \mathrm{NCH},{ }^{2} J(\mathrm{HH})=6.9 \mathrm{~Hz}\right), 2.57(\mathrm{~s}, \mathrm{~b}, \mathrm{NH}$, exchange with $\left.\mathrm{D}_{2} \mathrm{O}\right), 1.24\left(\mathrm{~d}, \mathrm{CH}_{3},{ }^{2} \mathrm{~J}(\mathrm{HH})=6.9 \mathrm{~Hz}\right) .{ }^{31} \mathrm{P}\left\{{ }^{1} \mathrm{H}\right\} \mathrm{NMR}\left(\mathrm{CDCl}_{3}\right): 32.85(\mathrm{~s})$.

\section{Synthesis of $(R, S)-\mathrm{Ph}_{2} \mathrm{P}(\mathrm{O}) \mathrm{CH}(\mathrm{Ph}) \mathrm{NHCH}(\mathrm{Ph}) \mathrm{CH}_{3}, 2$.}

To a solution of $(S)-\mathrm{PhCH}=\mathrm{NCH}(\mathrm{Ph}) \mathrm{CH}_{3}(0.940 \mathrm{~g}, 4.50 \mathrm{mmol})$ in $\mathrm{Et}_{2} \mathrm{O}(15 \mathrm{ml})$ was added $\mathrm{Ph}_{2} \mathrm{PH}(0.8 \mathrm{ml}, 4.50 \mathrm{mmol})$. After a few secondes a white precipitate was formed. The suspension was stirred for $5 \mathrm{~h}$ under an inert atmosphere. An air flow was then introduced into the $\mathrm{Et}_{2} \mathrm{O}$ solution for 10 minutes in order to displace all inert gas, and stirring was continued for $20 \mathrm{~h}$ in air to complete the oxidation. The white powder was collected by filtration $(1.51 \mathrm{~g})$, dried under vacuum and dissolved in hot methanol $(50 \mathrm{ml})$. After several days at $-30^{\circ} \mathrm{C}$, white needles were obtained and identified as the pure $(R, S)$ isomer of $2(0.966 \mathrm{~g}, 56 \%)$. Single crystals of syn-2 were obtained by slow diffusion of an EtOH solution of $\mathbf{2}$ onto the same volume of water. NMR data of pure syn-2: ${ }^{1} \mathrm{H}$ NMR $\left(\mathrm{CDCl}_{3}\right): \delta=7.98-7.09\left(\mathrm{~m}\right.$, aromatics), $4.62\left(\mathrm{~d}, \mathrm{PCH},{ }^{2} J(\mathrm{PH})=10.3 \mathrm{~Hz}\right)$, $3.64\left(\mathrm{q}, \mathrm{NCH},{ }^{2} J(\mathrm{HH})=6.8 \mathrm{~Hz}\right), 2.50\left(\mathrm{~s}, \mathrm{~b}, \mathrm{NH}\right.$, exchange with $\left.\mathrm{D}_{2} \mathrm{O}\right), 1.26\left(\mathrm{~d}, \mathrm{CH}_{3},{ }^{2} J(\mathrm{HH})=6.8\right.$ Hz). ${ }^{31} \mathrm{P}\left\{{ }^{1} \mathrm{H}\right\}$ NMR $\left(\mathrm{CDCl}_{3}\right): 31.64$ (s). ${ }^{13} \mathrm{C}\left\{{ }^{1} \mathrm{H}\right\}$ NMR $\left(\mathrm{CDCl}_{3}\right): \delta=148.32-128.82(\mathrm{~m}, \mathrm{C}-$ aromatics), $60.40\left(\mathrm{~d}, \mathrm{PCH},{ }^{1} J(\mathrm{PC})=78.6 \mathrm{~Hz}\right), 55.25\left(\mathrm{~d}, \mathrm{NCH},{ }^{3} J(\mathrm{PC})=11.4 \mathrm{~Hz}\right), 21.95\left(\mathrm{~s}, \mathrm{CH}_{3}\right)$. IR: $v_{\mathrm{P}=\mathrm{O}}=1270 \mathrm{~cm}^{-1}\left(\mathrm{CH}_{2} \mathrm{Cl}_{2}\right), 1265 \mathrm{~cm}^{-1}\left(\mathrm{CHCl}_{3}\right) . \mathrm{mp}=187^{\circ} \mathrm{C} \cdot[\alpha]_{\mathrm{D}}\left(\mathrm{CH}_{2} \mathrm{Cl}_{2}, 25^{\circ} \mathrm{C}, c=3.27\right.$ $\mathrm{g} / 100 \mathrm{ml})=-63^{\circ}$. Elemental analysis: Calcd for $\mathrm{C}_{27} \mathrm{H}_{26} \mathrm{NOP}$ : C 78.81, H 6.37, N 3.41; Found: $\mathrm{C}$ 78.83, H 6.45, N 3.77 .

\section{Synthesis of $(R, S)$ - and $(S, S)-\mathrm{Ph}_{2} \mathrm{P}(\mathrm{S}) \mathrm{CH}(\mathrm{Ph}) \mathrm{NHCH}(\mathrm{Ph}) \mathrm{CH}_{3}, 3$.}

To a solution of $(S)-\mathrm{PhCH}=\mathrm{NCH}(\mathrm{Ph}) \mathrm{CH}_{3}(0.739 \mathrm{~g}, 3.54 \mathrm{mmol})$ in $\mathrm{CH}_{2} \mathrm{Cl}_{2}(10 \mathrm{ml})$ was added $\mathrm{Ph}_{2} \mathrm{PH}(0.63 \mathrm{ml}, 3.54 \mathrm{mmol})$. The mixture was stirred for $3 \mathrm{~h}$ under an inert atmosphere, leading 
to a pale yellow solution. Molecular sulfur $(0.139 \mathrm{~g}, 4.34 \mathrm{mmol})$ was introduced into the solution and stirring was continued for seven days at room temperature. The solvent was then removed under vacuum leaving an orange viscous oil. The NMR analysis of this crude product showed both diastereomers of $\mathbf{3}$ with a d.e.(anti) of $70 \%$, slightly contaminated by the imine and the diphenylphosphine sulfide. Crystallization from methanol at $-80{ }^{\circ} \mathrm{C}$ afforded the pure ligand $(1: 1$ diastereomeric mixture) as a white powder $(0.144 \mathrm{~g}, 29 \%)$. Single crystals were obtained by slow diffusion of an ethanolic solution of $\mathbf{3}$ onto the same volume of water. NMR data of anti-3: ${ }^{1} \mathrm{H}$ $\operatorname{NMR}\left(\mathrm{C}_{6} \mathrm{D}_{6}\right): 8.01-6.69\left(\mathrm{~m}\right.$, aromatics), $4.53\left(\mathrm{~d}, \mathrm{PCH},{ }^{2} J(\mathrm{PH})=11.7 \mathrm{~Hz}\right), 3.60\left(\mathrm{q}, \mathrm{NCH},{ }^{2} J(\mathrm{HH})=\right.$ $6.2 \mathrm{~Hz}), 3.23(\mathrm{~s}, \mathrm{br}, \mathrm{NH}), 1.21\left(\mathrm{~d}, \mathrm{CH}_{3},{ }^{2} J(\mathrm{PH})=6.5 \mathrm{~Hz}\right) .{ }^{31} \mathrm{P}\left\{{ }^{1} \mathrm{H}\right\} \operatorname{NMR}\left(\mathrm{C}_{6} \mathrm{D}_{6}\right): 50.28$ (s), $\left(\mathrm{CDCl}_{3}\right): 50.25$ (s). ${ }^{13} \mathrm{C}\left\{{ }^{1} \mathrm{H}\right\}$ NMR $\left(\mathrm{CDCl}_{3}\right):$ 145.01-127.06 (m, C-aromatics), 59.16 (d, PCH, $\left.{ }^{1} J(\mathrm{PC})=66.20 \mathrm{~Hz}\right), 55.00\left(\mathrm{~d}, \mathrm{NCH},{ }^{3} J(\mathrm{PC})=14.8 \mathrm{~Hz}\right), 24.64\left(\mathrm{~s}, \mathrm{CH}_{3}\right)$. NMR data of $\operatorname{syn}-3:{ }^{1} \mathrm{H}$ NMR $\left(\mathrm{C}_{6} \mathrm{D}_{6}\right):$ 8.01-6.69 (m, aromatics), $4.92\left(\mathrm{~d}, \mathrm{PCH},{ }^{2} J(\mathrm{PH})=9.1 \mathrm{~Hz}\right), 3.73\left(\mathrm{q}, \mathrm{NCH},{ }^{2} J(\mathrm{HH})=\right.$ $6.2 \mathrm{~Hz}), 3.43\left(\mathrm{~s}, \mathrm{br}, \mathrm{NH}\right.$, exchange with $\left.\mathrm{D}_{2} \mathrm{O}\right), 1.45\left(\mathrm{~d}, \mathrm{CH}_{3},{ }^{2} J(\mathrm{HH})=6.7 \mathrm{~Hz}\right) .{ }^{31} \mathrm{P}\left\{{ }^{1} \mathrm{H}\right\}$ NMR ( $\left.\mathrm{C}_{6} \mathrm{D}_{6}\right): 50.68$ (s), $\left(\mathrm{CDCl}_{3}\right): 50.42(\mathrm{~s}) .{ }^{13} \mathrm{C}\left\{{ }^{1} \mathrm{H}\right\} \mathrm{NMR}\left(\mathrm{CDCl}_{3}\right)$ : 145.01-127.06 (m, C-aromatics), $60.37\left(\mathrm{~d}, \mathrm{PCH},{ }^{1} J(\mathrm{PC})=58.35 \mathrm{~Hz}\right), 55.21\left(\mathrm{~d}, \mathrm{NCH},{ }^{3} J(\mathrm{PC})=10.11 \mathrm{~Hz}\right), 22.84\left(\mathrm{~s}, \mathrm{CH}_{3}\right) . \quad \mathrm{IR}$ $\left(\mathrm{CHCl}_{3}\right) v_{\mathrm{P}=\mathrm{S}}=1103 \mathrm{~cm}^{-1} . \mathrm{mp}=115^{\circ} \mathrm{C}$. Elemental analysis: Calcd for $\mathrm{C}_{27} \mathrm{H}_{26} \mathrm{NSP}(\mathrm{MW}: 427.15)$ : C 75.85, H 6.13, N 3.28, S 7.48. Found: C 75.70, H 6.25, N 3.32, S 7.47.

\section{Catalytic runs}

The hydroformylation reactions were carried out in a 300-ml stainless-steel Parr autoclave equipped with a magnetic drive and an internal glass vessel. The temperature was controlled by a rigid heating mantle and by a single loop cooling coil. The autoclave was purged three times under vacuum/argon before introducing the catalytic solution (for the amounts used, see footnote 
of Table 2). The 1:1 CO/ $\mathrm{H}_{2}$ mixture was prepared by mixing the pure gases in a $500-\mathrm{ml}$ stainless steel cylinder before introduction into the autoclave at the desired pressure (see Table 2). The zero time for the kinetic runs (see Figure 3) was considered as the time at which the desired temperature (Table 2) was reached inside the autoclave. In order to maintain as constant temperature and pressure conditions as possible during each kinetic run, only a few $\mathrm{ml}$ of the catalytic solution mixture were carefully withdrawn each time from the autoclave under pressure. The $\mathrm{CHCl}_{3}$ or $\mathrm{C}_{6} \mathrm{D}_{6}$ solvent was then rotary evaporated at room temperature and the yelloworange viscous residue was analysed by ${ }^{1} \mathrm{H}$ and ${ }^{31} \mathrm{P}$ NMR spectroscopies in $\mathrm{CDCl}_{3}$ solution.

\section{Crystal structure analyses of compounds syn -2 and syn/anti-3}

Single crystals of syn-2 and syn/anti-3 were obtained by slow diffusion of an ethanolic solution of $\mathbf{2}$ or $\mathbf{3}$ onto the same volume of water. Intensity data were collected on a Nonius Kappa CCD at $293 \mathrm{~K}$ for syn $\mathbf{- 2}$ and $110 \mathrm{~K}$ for syn/anti-3. Both structures were solved by direct methods and refined by full-matrix least-squares methods (SHELXL-97) ${ }^{33}$ with the aid of the WINGX program. ${ }^{34}$ Non-hydrogen atoms were anisotropically refined. With the exception of the NH hydrogen atom (for both compounds), which was located in the final difference Fourier maps and refined freely, all hydrogen atoms were included in a riding model. Crystallographic data for compounds syn -2 and syn/anti-3 are reported Table 3.

\section{Acknowledments}

We are grateful to the Ministère de l'Education Nationale, de la Recherche et de la Technologie (MENRT) for support and for a PhD fellowship (to J.-M. C.), the Centre National de 
la Recherche Scientifique (CNRS) and the Conseil Regional de Bourgogne for support of this work and Mr Cédric Balan for technical assistance.

\section{References}

1 S. Gladiali, J. C. Bayon and C. Claver, Tetrahedron: Asymmetry, 1995, 6, 1453-1474.

2 F. Agbossou, J.-F. Carpentier and A. Mortreux, Chem. Rev., 1995, 95, 2485-2506.

3 J. P. Rieu, A. Bouchere, H. Cousse and G. Mouzin, Tetrahedron, 1986, 42, 4095-4131.

4 H. R. Sonawane, N. S. Bellur, J. R. Ahuja and D. G. Ulkarni, Tetrahedron: Asymmetry, 1992, 3, 163-192.

5 M. Diéguez, O. Pàmies, A. Ruiz, S. Castillón and C. Claver, J. Chem. Soc., Chem. Comm., 2000, 1607-1608.

6 N. Sakai, S. Mano, K. Nozaki and H. Takaya, J. Am. Chem. Soc., 1993, 115, 7033-7034.

7 F. Fache, E. Schultz, M. Lorraine Tommasino and M. Lemaire, Chem. Rev., 2000, 100, 2159-2231.

8 J. A. J. Breuzard, M. Lorraine Tommasino, F. Touchard, M. Lemaire and M. C. Bonnet, J. Mol. Catal. A: Chem., 2000, 156, 223-232.

9 C. Abu-Gnim and I. Amer, J. Chem. Soc., Chem. Commun., 1994, 115-117.

10 C. Abu-Gnim and I. Amer, J. Organomet. Chem., 1996, 516, 235-243.

11 C. Basoli, C. Botteghi, M. A. Cabras, G. Chelucci and M. Marchetti, J. Organomet. Chem., 1995, 488, C20-C22.

12 K. Yamakoshi, S. J. Harwood, M. Kanai and M. Shibasaki, Tetrahedron Lett., 1999, 40, 2565-2568. 
13 A. M. Maj, K. M. Pietrusiewicz, I. Suisse, F. Agbossou and A. Mortreux, Tetrahedron: Asymmetry, 1999, 10, 831-835.

14 J. Andrieu, J. Dietz, R. Poli and P. Richard, New J. Chem., 1999, 23, 581-583.

15 J. Andrieu, C. Baldoli, S. Maiorana, R. Poli and P. Richard, Eur. J. Org. Chem., 1999, 3095-3097.

16 G. Alvaro, C. Boga, D. Savoia and A. Umani-Ronchi, J. Chem. Soc., Perkin Trans. 1, $1996,875-882$.

17 M. B. Eleveld, H. Hogeveen and E. P. Schudde, J. Org. Chem., 1986, 51, 3635-3642.

18 I. Le Gall, P. Laurent, E. Soulier, J. Y. Salaün and H. des Abbayes, J. Organomet. Chem., 1998, 567, 13-20.

19 B. Patel, S. J. A. Pope and G. Reid, Polyhedron, 1998, 17, 2345-2351.

20 M. J. Baker, M. F. Giles, A. G. Orpen, M. J. Taylor and R. J. Watt, J. Chem. Soc., Chem. Commun., 1995, 197-198.

21 S. O. Grim and E. D. Walton, Inorg. Chem., 1980, 19, 1982-1987.

22 M. T. Pinillos, M. P. Jarauta, D. Carmona, L. A. Oro, M. C. Apreda, C. Foces-Foces and F. H. Cano, J. Chem. Soc., Dalton Trans., 1989, 1987-1992.

23 M. T. Pinillos, M. P. Jarauto, D. Carmona, L. A. Oro, M. C. Apreda, C. Foces-Foces and F. H. Cano, J. Organomet. Chem., 1988, 345, C13-C16.

24 C. G. Arena, F. Nicolò, D. Drommi, G. Bruno and F. Faraone, J. Chem. Soc., Chem. Commun., 1994, 2251-2252.

25 G. Chelucci, M. Marchetti and B. Sechi, J. Mol. Catal. A: Chem., 1997, 122, 111-114.

26 S. Naili, I. Suisse, A. Mortreux, F. Agbossou, M. Ait Ali and A. Karim, Tetrahedron Lett., 2000, 41, 2867-2870. 
27 M. Otto, J. Parr and A. M. Z. Slawin, Organometallics, 1998, 17, 4527-4529.

28 A. G. Abatjoglou, E. Billig and D. R. Bryant, Organometallics, 1984, 3, 923-926.

29 A. G. Abatjoglou and D. R. Bryant, Organometallics, 1984, 3, 932-934.

30 S. Sjövall, P. H. Svensson and C. Andersson, Organometallics, 1999, 18, 5412-5415.

31 G. Reddelien, Ber., 1913, 46, 2718-2723.

32 W. Hewertson and H. R. Watson, J. Chem. Soc., 1962, 1490-1494.

33 G. M. Sheldrick, SHELX97 (Includes SHELXS-97, SHELXL-97)-Programs for Crystal Structure Analysis (Release 97-2). University of Göttingen, Germany., 1998.

34 L. J. Farrugia, J. Appl. Crystallogr., 1999, 32, 837-838.

35 H. D. Flack, Acta Cryst., 1983, A39, 876-881.

36 G. Bernardinelli and H. D. Flack, Acta Cryst., Sect A, 1985, 41, 500-511. 
Table 1. Selected bond distances $(\AA)$ and angles $\left(^{\circ}\right)$ for compounds syn -2 and syn/anti-3.

\begin{tabular}{lrcc} 
& $s y n-2(\mathrm{E}=\mathrm{O})$ & syn $\mathbf{- 3}(\mathrm{E}=\mathrm{S})$ & anti $\mathbf{- 3}(\mathrm{E}=\mathrm{S})$ \\
\hline $\mathrm{P}-\mathrm{E}$ & $1.4870(13)$ & $1.9642(9)$ & $1.9651(8)$ \\
$\mathrm{P}-\mathrm{C}(1)$ & $1.832(2)$ & $1.893(3)$ & $1.856(2)$ \\
$\mathrm{N}-\mathrm{C}(1)$ & $1.462(2)$ & $1.452(3)$ & $1.463(3)$ \\
E-P-C(1) & $116.66(8)$ & $111.17(8)$ & $112.69(8)$ \\
P-C (1)-N & $104.82(12)$ & $111.32(16)$ & $103.90(14)$ \\
H-C (1)-P-E & $170(1)$ & $157(1)$ & $163(1)$
\end{tabular}


Table 2. Hydroformylation of styrene catalyzed by $[\mathrm{RhCl}(\mathrm{COD})]_{2}$ and aminophosphine oxide $\left(\right.$ syn-2) or sulfide $\left(\right.$ syn/anti-3) ligands ${ }^{\mathrm{a}}$

\begin{tabular}{cccccccc} 
Entry & solvent & Ligand & $\mathrm{T}\left({ }^{\circ} \mathrm{C}\right)$ & $\mathrm{P}(\mathrm{psi})$ & $\%$ conversion $^{\mathrm{b}}($ time $)$ & $\% \mathrm{~b} / 1^{\mathrm{b}}$ \\
\hline 1 & $\mathrm{CHCl}_{3}$ & --- & 55 & 400 & $4(3 \mathrm{~h})$ & $100(20 \mathrm{~h})$ & $89 / 11$ \\
2 & $\mathrm{CHCl}_{3}$ & $\mathbf{2}$ & 55 & 400 & $88(3 \mathrm{~h})$ & $100(4 \mathrm{~h})$ & $89 / 11$ \\
3 & $\mathrm{C}_{6} \mathrm{H}_{6}$ & $\mathbf{2}$ & 55 & 400 & $16(3 \mathrm{~h})$ & $100(21 \mathrm{~h})^{\mathrm{c}}$ & $85 / 15$ \\
4 & $\mathrm{CHCl}_{3}$ & $\mathbf{2}$ & 35 & 500 & $60(3 \mathrm{~h})$ & $100(6 \mathrm{~h})^{\mathrm{c}}$ & $96 / 4$ \\
$5^{\mathrm{d}}$ & $\mathrm{CHCl}_{3}$ & $\mathbf{2}$ & 35 & 500 & $35(3 \mathrm{~h})$ & $100(8 \mathrm{~h})^{\mathrm{e}}$ & $96 / 4$ \\
6 & $\mathrm{CHCl}_{3}$ & $\mathbf{3}$ & 55 & 400 & $0(3 \mathrm{~h})$ & $30(70 \mathrm{~h})$ & $95 / 5$ \\
$7^{\mathrm{f}}$ & $\mathrm{CHCl}_{3}$ & $\mathbf{3}$ & 55 & 400 & $0(3 \mathrm{~h})$ & $30(67 \mathrm{~h})$ & $93 / 7$ \\
8 & $\mathrm{CHCl}_{3}$ & $\mathrm{Ph}_{2} \mathrm{P}(\mathrm{O}) \mathrm{H}$ & 35 & 500 & $3(3 \mathrm{~h})$ & $50(21 \mathrm{~h})$ & $96 / 4$
\end{tabular}

${ }^{a}$ Reaction conditions: $[\mathrm{RhCl}(\mathrm{COD})]_{2} \quad(0.025 \mathrm{mmol})$, solvent $(40 \mathrm{ml}), \quad \mathrm{CO}+\mathrm{H}_{2} \quad(1: 1)$, styrene/Rh/ligand: $167 / 1 / 1$. ${ }^{b}$ Determined by ${ }^{1} \mathrm{H}$ NMR spectroscopy, no ethylbenzene detected. ${ }^{\mathrm{c}}$ The e.e. at complete conversion is $0 \%$. ${ }^{\mathrm{d}}$ Vinylnaphthalene used instead of styrene under similar conditions. ${ }^{\text {e}}$ The e.e. at complete conversion is $3 \% .{ }^{\mathrm{f}}\left[\mathrm{Rh}(\mathrm{COD})_{2}\right]\left(\mathrm{CF}_{3} \mathrm{SO}_{3}\right)$ used instead of $[\mathrm{RhCl}(\mathrm{COD})]_{2}$ under similar conditions. 
Table 3. Crystal data and structure refinement for syn -2 and syn/anti-3.

\begin{tabular}{|c|c|c|}
\hline Compound & syn -2 & syn/anti-3 \\
\hline Formula & $\mathrm{C}_{27} \mathrm{H}_{26} \mathrm{NOP}$ & $\mathrm{C}_{27} \mathrm{H}_{26} \mathrm{NSP}$ \\
\hline M & 411.46 & 427.52 \\
\hline $\mathrm{T} ; \mathrm{K}$ & $293(2)$ & $110(2)$ \\
\hline Crystal system & orthorhombic & monoclinic \\
\hline Space group & $P 2_{1} 2_{1} 2_{1}$ & $P 2_{1}$ \\
\hline $\mathrm{a} ; \AA$ & $5.804(1)$ & $9.0532(4)$ \\
\hline $\mathrm{b} ; \AA$ & $16.911(3)$ & $18.5975(9)$ \\
\hline $\mathrm{c} ; \AA$ & $23.518(6)$ & $13.4262(8)$ \\
\hline $\mathrm{a} ;{ }^{\circ}$ & 90 & 90 \\
\hline $\mathrm{b} ;{ }^{\circ}$ & 90 & $92.218(2)$ \\
\hline $\mathrm{g}, \stackrel{\circ}{\circ}$ & 90 & 90 \\
\hline $\mathrm{V} ; \AA^{3}$ & $2308.3(8)$ & $2258.8(2)$ \\
\hline Z & 4 & 8 \\
\hline $\mathrm{F}(000)$ & 872 & 904 \\
\hline$D_{\text {calc }} ; \mathrm{g} / \mathrm{cm}^{3}$ & 1.184 & 1.257 \\
\hline diffractometer & Kappa CCD & Kappa CCD \\
\hline scan type & $\begin{array}{l}\text { mixture of } \phi \text { rotations } \\
\text { and } \omega \text { scans }\end{array}$ & $\begin{array}{l}\text { mixture of } \phi \text { rotations } \\
\text { and } \omega \text { scans }\end{array}$ \\
\hline$\lambda ; \AA$ & 0.71073 & 0.71073 \\
\hline$\mu ; \mathrm{mm}^{-1}$ & 0.137 & 0.228 \\
\hline Crystal size; $\mathrm{mm}^{3}$ & $0.35 \times 0.30 \times 0.24$ & $0.30 \times 0.18 \times 0.12$ \\
\hline $\sin (\theta) / \lambda \max ; \AA^{-1}$ & 0.61 & 0.65 \\
\hline \multirow[t]{3}{*}{ Index ranges } & h: $-6 ; 7$ & h: $-11 ; 11$ \\
\hline & k: $-20 ; 20$ & $\mathrm{k}:-24 ; 23$ \\
\hline & $1:-28 ; 28$ & 1: $-17 ; 17$ \\
\hline $\mathrm{RC}=$ Refl. Collected & 8469 & 14691 \\
\hline $\mathrm{IRC}=$ independent $\mathrm{RC}$ & $4099[\mathrm{R}(\mathrm{int})=0.025]$ & $9440[\mathrm{R}(\mathrm{int})=0.033]$ \\
\hline IRCGT $=\mathrm{IRC}$ and $[\mathrm{I}>2 \sigma(\mathrm{I})]$ & 3776 & 7329 \\
\hline Refinement method & Full-matrix L.S. on $\mathrm{F}^{2}$ & Full-matrix L.S. on $\mathrm{F}^{2}$ \\
\hline Data / restraints / param. & 4099 / 0 / 278 & $9440 / 1 / 549$ \\
\hline $\mathrm{R}$ for IRCGT & $\mathrm{R} 1^{\mathrm{a}}=0.036, \mathrm{wR} 2^{\mathrm{b}}=0.086$ & $\mathrm{R} 1^{\mathrm{a}}=0.042, \mathrm{wR} 2^{\mathrm{b}}=0.075$ \\
\hline $\mathrm{R}$ for IRC & $\mathrm{R} 1^{\mathrm{a}}=0.041, \mathrm{wR} 2^{\mathrm{b}}=0.089$ & $\mathrm{R} 1^{\mathrm{a}}=0.069, \mathrm{wR} 2^{\mathrm{b}}=0.083$ \\
\hline Goodness-of-fit ${ }^{\mathrm{c}}$ & 1.045 & 0.992 \\
\hline Flack parameter $^{\mathrm{d}}$ & $0.00(9)$ & $0.01(5)$ \\
\hline$\Delta \rho, \max , \min ; \mathrm{e} \cdot \AA^{-3}$ & 0.129 and -0.152 & 0.271 and -0.261 \\
\hline
\end{tabular}


Figure 1. Kinetic and thermodynamic controls in the formation of chiral $\alpha-P, N(\mathbf{1})$ ligands.

Figure 2. ORTEP views of compounds syn-2 (a) and syn/anti-3 (b). The two diastereomers in the latter view are shown in their correct relative orientation. Thermal ellipsoids are drawn at the $30 \%$ probability level for (a) and $50 \%$ for (b). For clarity, only relevant hydrogen atoms are shown.

Figure 3. Conversion as a function of time for the hydroformylation of styrene at various syn2/Rh ratios: 0.5 (squares), 1 (triangles), 2 (circles), 10 (inverted triangles). Reaction conditions: $[\mathrm{RhCl}(\mathrm{COD})]_{2}(0.025 \mathrm{mmol}), 30 \mathrm{ml}$ of $\mathrm{CHCl}_{3}, \mathrm{~T}=35^{\circ} \mathrm{C}, \mathrm{P}\left(\mathrm{CO} / \mathrm{H}_{2} 1: 1\right)=$ 500 psi. The conversion and regioselectivity (95 to $97 \%$ for all experiments) were determined by ${ }^{1} \mathrm{H}$ NMR spectroscopy.

Figure 4. Rhodium-catalyzed epimerization of $\left[\mathrm{Ph}_{2} \mathrm{P}(\mathrm{S}) \mathrm{CH}(\mathrm{Ph}) \mathrm{NHCH}(\mathrm{Ph}) \mathrm{Me}\right]$. Reaction conditions: ligand $/ \mathrm{Rh}$ ratio $=10, \mathrm{C}_{6} \mathrm{D}_{6}(0.5 \mathrm{ml})$ at R.T. Squares: $[\mathrm{RhCl}(\mathrm{COD})]_{2}(0.05$ mmol); triangles: $\left[\mathrm{RhCl}(\mathrm{CO})_{2}\right]_{2}(0.05 \mathrm{mmol})$.

Figure 5. Fitting of the kinetic data from Figure 4 by equation 2 .

Figure 6. Rhodium-catalyzed epimerization of syn-2. Reaction conditions: $[\mathrm{RhCl}(\mathrm{COD})]_{2}$ $(0.025 \mathrm{mmol})$, solvent $=\mathrm{CHCl}_{3}(30 \mathrm{ml}), \mathrm{T}=35^{\circ} \mathrm{C}$. Circles: $\mathrm{CO}(\mathrm{P}=400 \mathrm{psi})$, ligand $/ \mathrm{Rh}$ ratio $=10$; triangles: $\mathrm{CO}-\mathrm{H}_{2}(1: 1, \mathrm{P}=400 \mathrm{psi})$, ligand $/ \mathrm{Rh}$ ratio $=10$; squares: $\mathrm{CO}-\mathrm{H}_{2}(1: 1, \mathrm{P}=400 \mathrm{psi})$, ligand $/ \mathrm{Rh}$ ratio $=5$. 


\section{Chart 1}

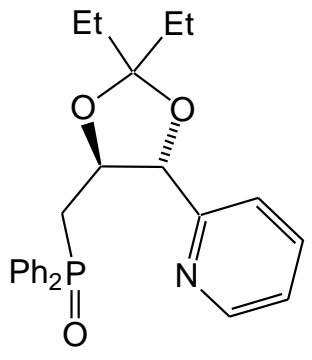

(B)<smiles>CN(C)C[PH](=O)c1ccccc1</smiles>

(A)<smiles>C[C@@H](NCCP(=O)([18OH])c1ccccc1)c1ccccc1</smiles>

(C)

\section{Chart 2}<smiles>C[C@H](N=Cc1ccccc1)c1ccccc1</smiles>

$$
\begin{aligned}
& \text { Optically pure } \\
& \text { diastereomers }
\end{aligned}
$$

Equation 1<smiles>C=CC(=[N-])N=Cc1ccccc1</smiles>

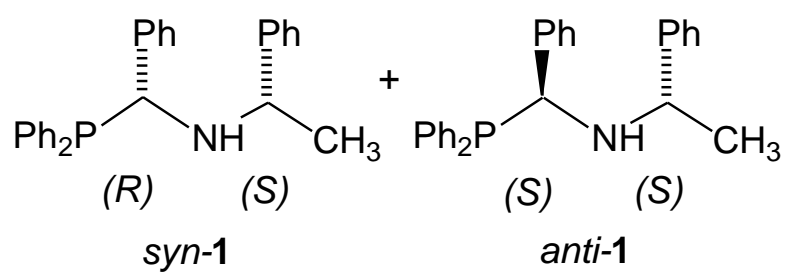


Figure 1

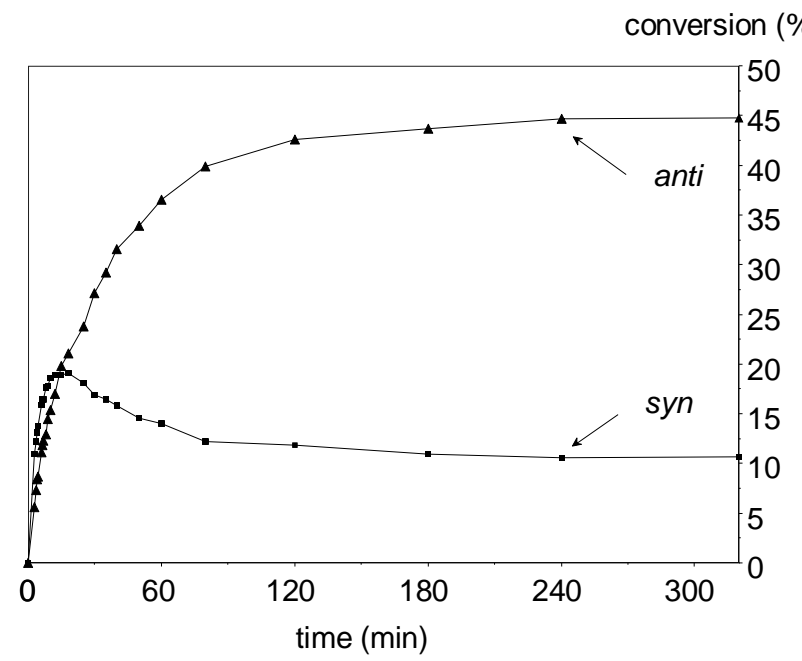


Figure 2.

(a)

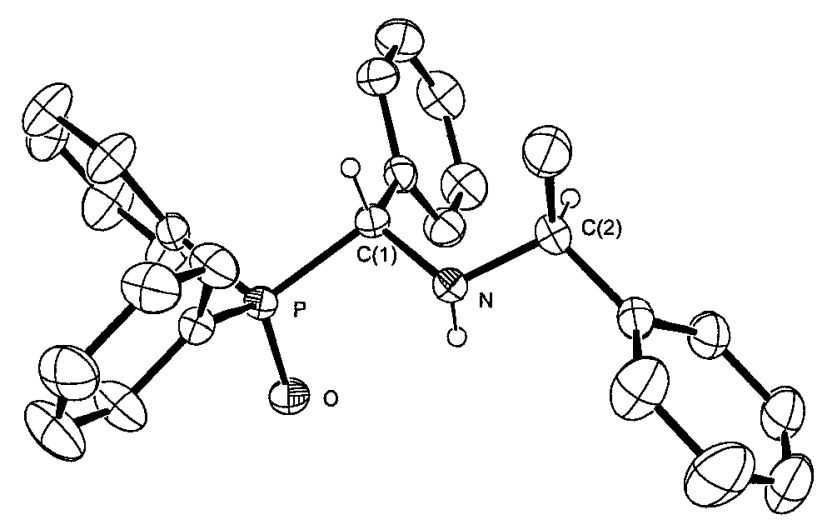

(b)
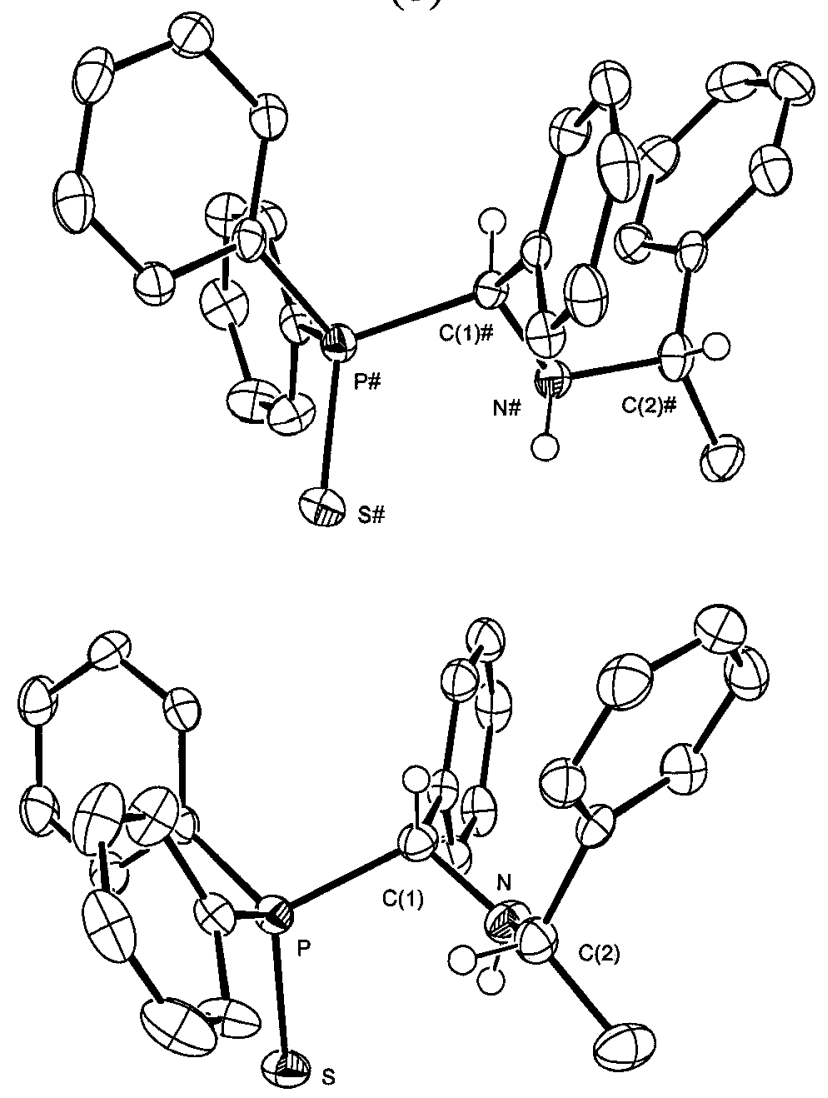
Figure 3

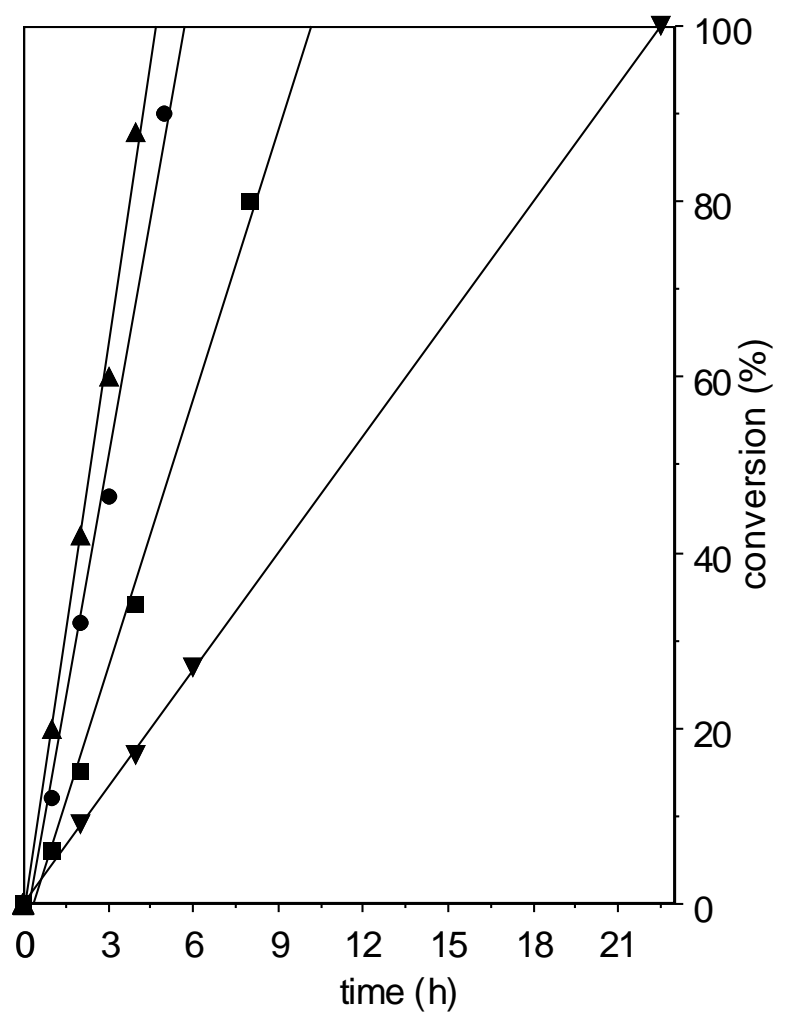


Figure 4

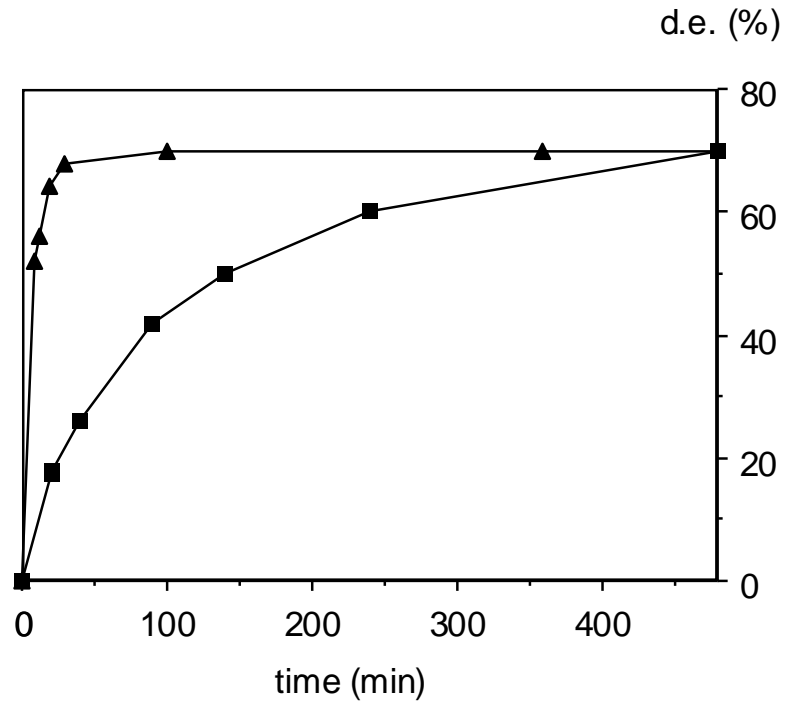


Figure 5

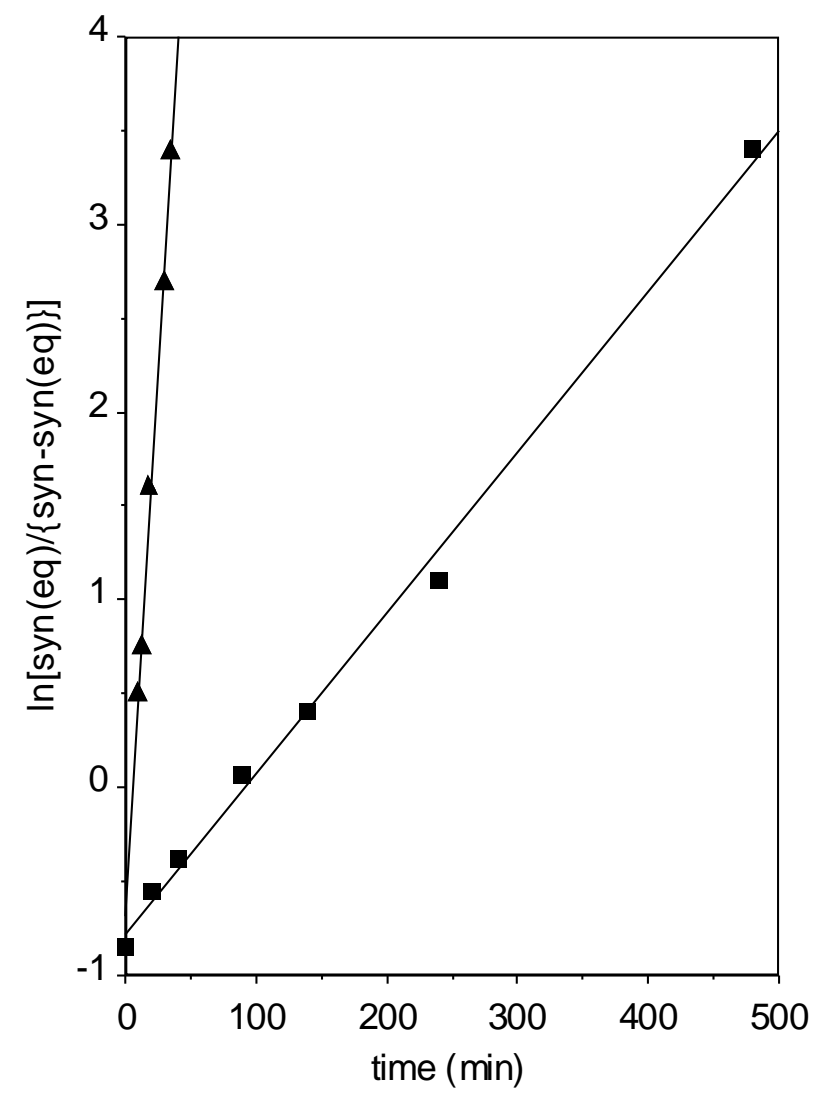


Figure 6

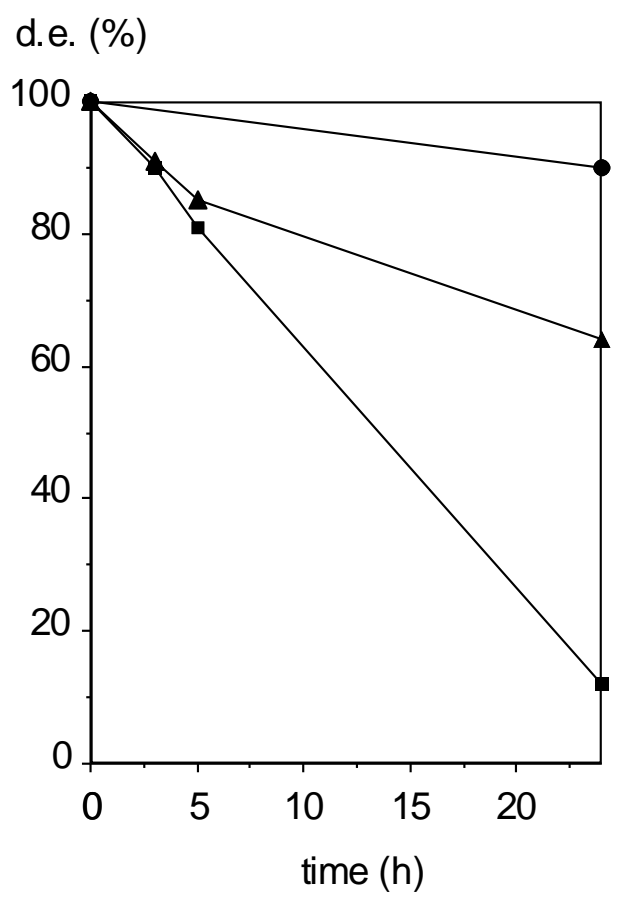


Scheme 1

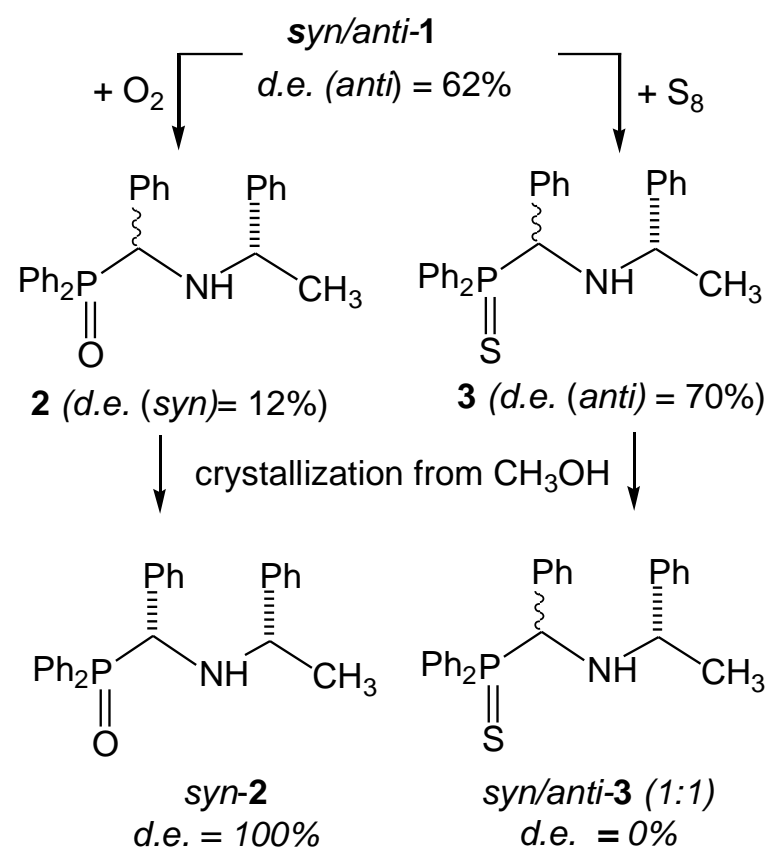

Scheme 2

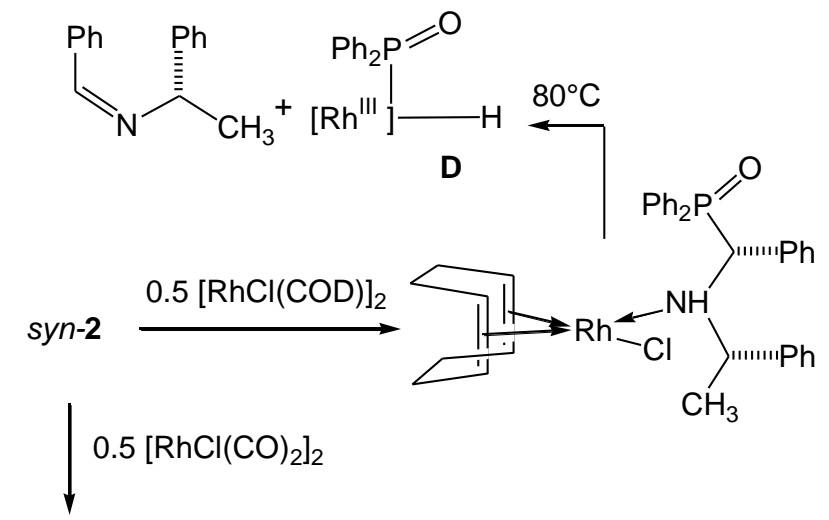

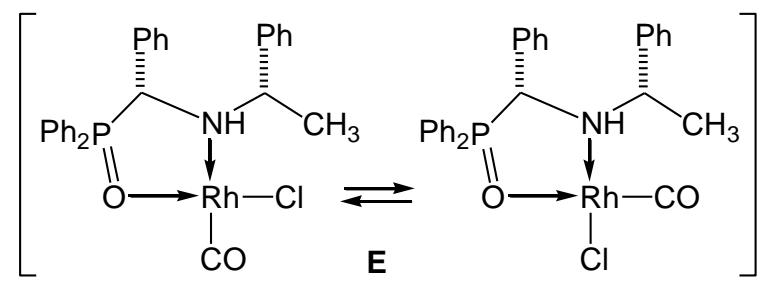


Scheme 3

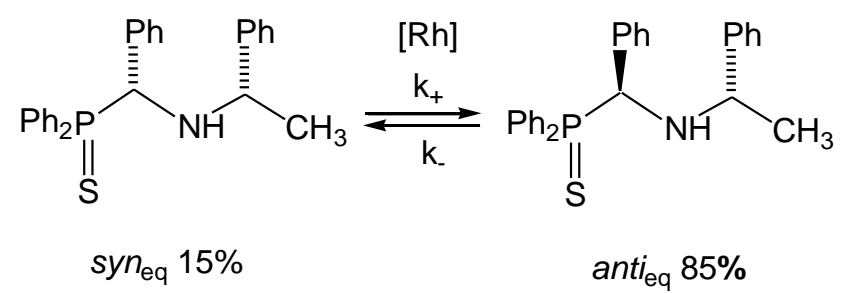

\begin{tabular}{c|cc}
{$[\mathrm{Rh}]$} & $\mathrm{k}_{+}\left(\mathrm{mol}^{-1} \mathrm{~L} \mathrm{~min}-1\right)$ & $\mathrm{k}_{-}\left(\mathrm{mol}^{-1} \mathrm{~L} \mathrm{~min}{ }^{-1}\right)$ \\
\hline $\mathrm{Rh}_{2} \mathrm{Cl}_{2}(\mathrm{CO})_{4}$ & $7.31(3) \times 10^{-2}$ & $1.29(3) \times 10^{-2}$ \\
$\mathrm{Rh}_{2} \mathrm{Cl}_{2}(\mathrm{COD})_{2}$ & $0.995(6)$ & $0.175(6)$
\end{tabular}

Scheme 4

reversible $\mathrm{C}-\mathrm{H}$ bond cleavage

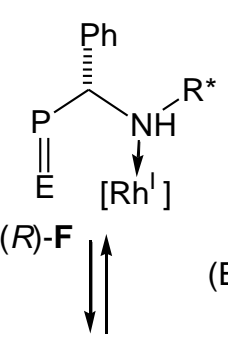

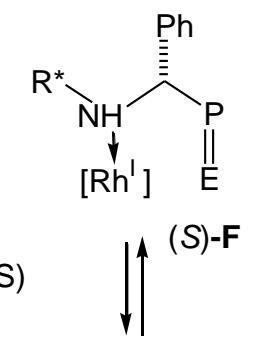

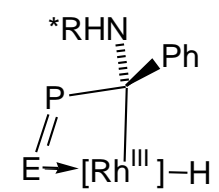

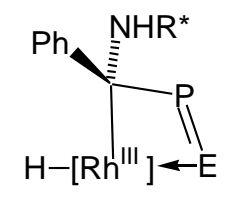

(R)-G
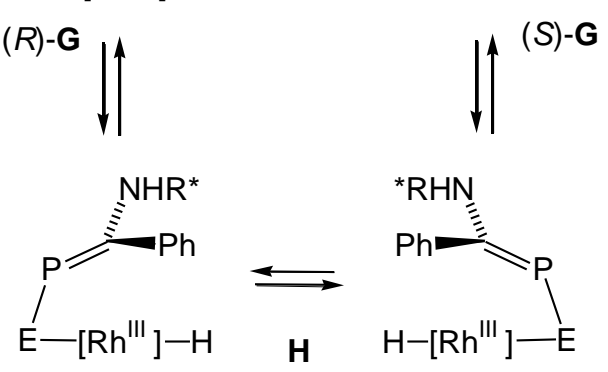<smiles>C=CPC(NP)=PC(P)I</smiles> 
Scheme 5

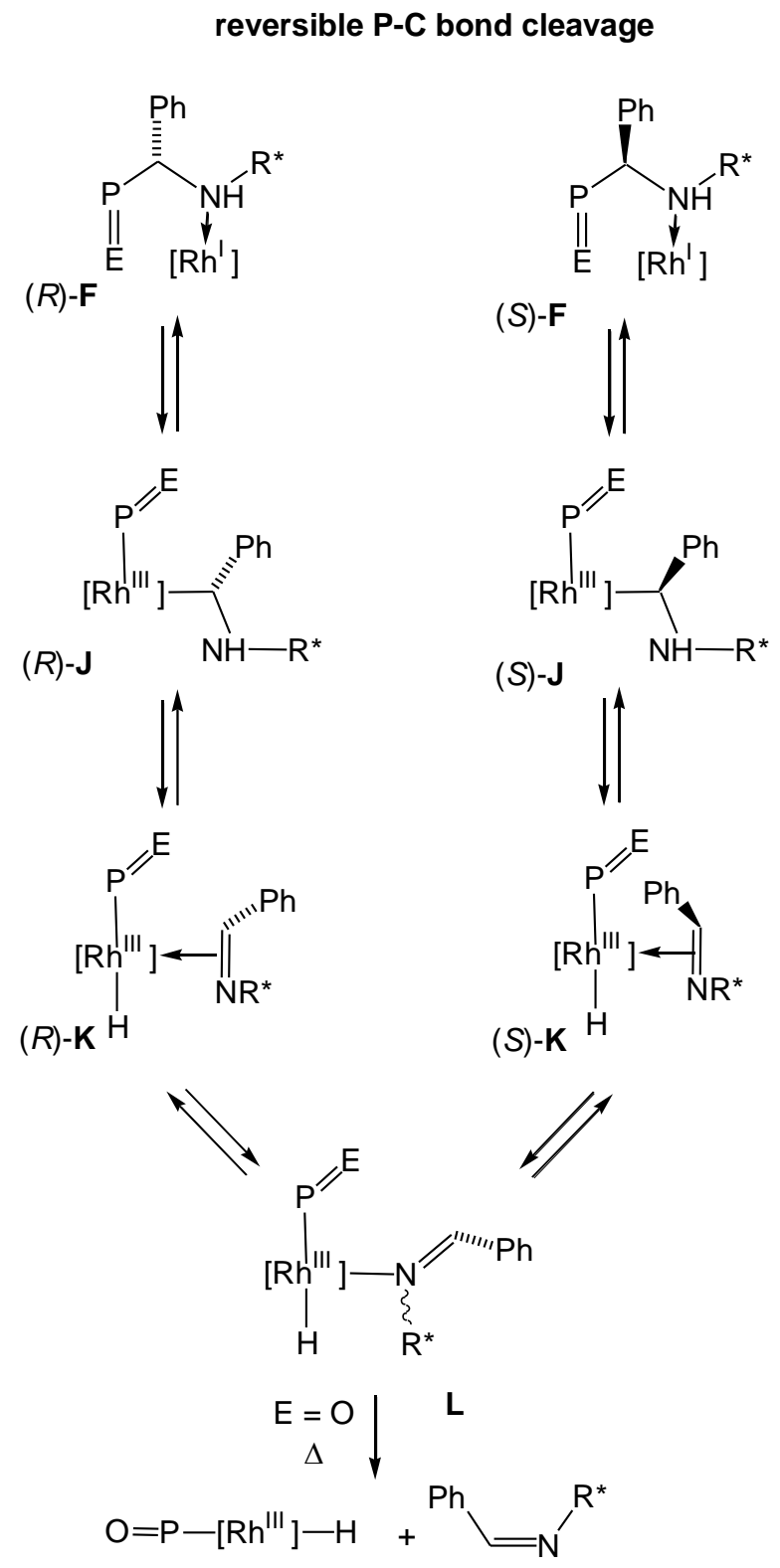

